Article

\title{
Geochemical Features and Geological Processes Timescale of the Achaean TTG Complexes of the Ingozero Massif and the Pechenga Frame (NE Baltic Shield)
}

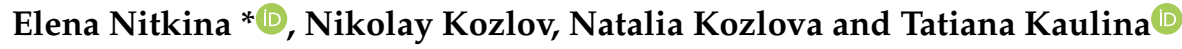 \\ Geological Institute, Kola Science Centre, Russian Academy of Sciences, Fersman Str. 14, 184209 Apatity, Russia; \\ kozlov@geoksc.apatity.ru (N.K.); xiao-nata@yandex.ru (N.K.); kaulina@geoksc.apatity.ru (T.K.) \\ * Correspondence: nitkina@rambler.ru; Tel.: +79-0213-745-78
}

Received: 1 November 2019; Accepted: 6 December 2019; Published: 10 December 2019

check for updates

\begin{abstract}
This article provides a geological review and results of the structural, metamorphic, and geochronological studies of the Pechenga frame outcrops located in the NW part of the Central-Kola terrain and the Ingozero massif outcrops situated in the northeastern part of the Belomorian mobile belt of the Kola Region (NW Baltic Shield). As a result of the work, the deformation scales and ages of the geological processes at the Neo-Archaean-Paleoproterozoic stage of the area's development were compiled, and the reference rocks were dated. The petrochemical and geochemical characteristics of the Ingozero rocks are similar to those of tonalite-trondhjemite-granodiorite (TTG) complexes established on other Archaean shields. The isotope $\mathrm{U}-\mathrm{Pb}$ dating of individual zircon grains from the biotite gneisses provided the oldest age for magmatic protolith of the Ingozero gneisses, which is $3149 \pm 46 \mathrm{Ma}$. Sm-Nd model ages showed that the gneisses protolite initial melt formed at 3.1-2.8 Ga. Ages of metamorphic processes were determined by using isotope U-Pb dating ID TIMS (isotope dilution thermal ionization mass spectrometry): Biotite gneisses-2697 $\pm 9 \mathrm{Ma}$; amphibole-biotite gneisses-2725 $\pm 2 \mathrm{Ma}$ and $2667 \pm 7 \mathrm{Ma}$; and biotite-amphibole gneisses $2727 \pm 5 \mathrm{Ma}$. Ages of granitoids, which cut the deformed gneisses, are $2615 \pm 8$ Ma and $2549 \pm 31$ Ma for plagiogranites and pegmatoid veins in gneisses, respectively. The following age sequence of geological processes was established by using $\mathrm{U}-\mathrm{Pb}$ zircon dating: $2.8 \mathrm{Ga}-$ The time of the garnet-biotite gneiss metamorphism; $2722 \pm 9 \mathrm{Ma}$-The granodiorite crystallization time; $2636 \pm 41 \mathrm{Ma}$-The aplite emplacement age and $2620 \pm 16 \mathrm{Ma}-$ The age of pegmatites origin, which marked final stages of the Archaean evolution; $2587 \pm 5 \mathrm{Ma}$-The age of gabbros emplacement and $2507 \pm 7 \mathrm{Ma}$ - The age of gabbros metamorphism; 2522-2503 Ma-The origin time of the iron quartzite interpreted as the age of gabbros and biotite gneiss metamorphism.
\end{abstract}

Keywords: geochemical features of the Archaean TTG; zircon isotope U-Pb dating and mineralogy; geology of Archaean complexes in the Kola Region

\section{Introduction}

The Ingozero massif and the Pechenga structure frame belong to the tonalite-trondhjemite-granodiorites complex, i.e., the TTG complex in the Kola Region (NE Baltic Shield) [1-3].

The Ingozero massif is located in the northeastern part of the Belomorsky mobile belt (Figure 1, [4,5]) and mainly composed of different gneisses and granitoids [1,6-9]. The massif stands out as an independent block on the geological map of the Kola Region. It is considered to be the oldest intrusion of granodiorites, tonalities, and plagiogranites surrounded by the TTG complex gneisses [2]. The Sm-Nd-model data of the Ingozero massif gneisses are in the range of 3.1-2.8 Ga [7], the U-Pb 
zircon age is $3.1 \mathrm{Ga}$ [10]. The data reflect the Mesoarchean age of the mantle source. Ages of the oldest rocks of the Kola Region were determined by detrital zircons dating, and are more than 3.0 Ga [10-13]. No igneous rocks of this age were found. The Ingozero massif geological setting and Mesoarchean ages make the isotope-geochronological study of the massif relevant.

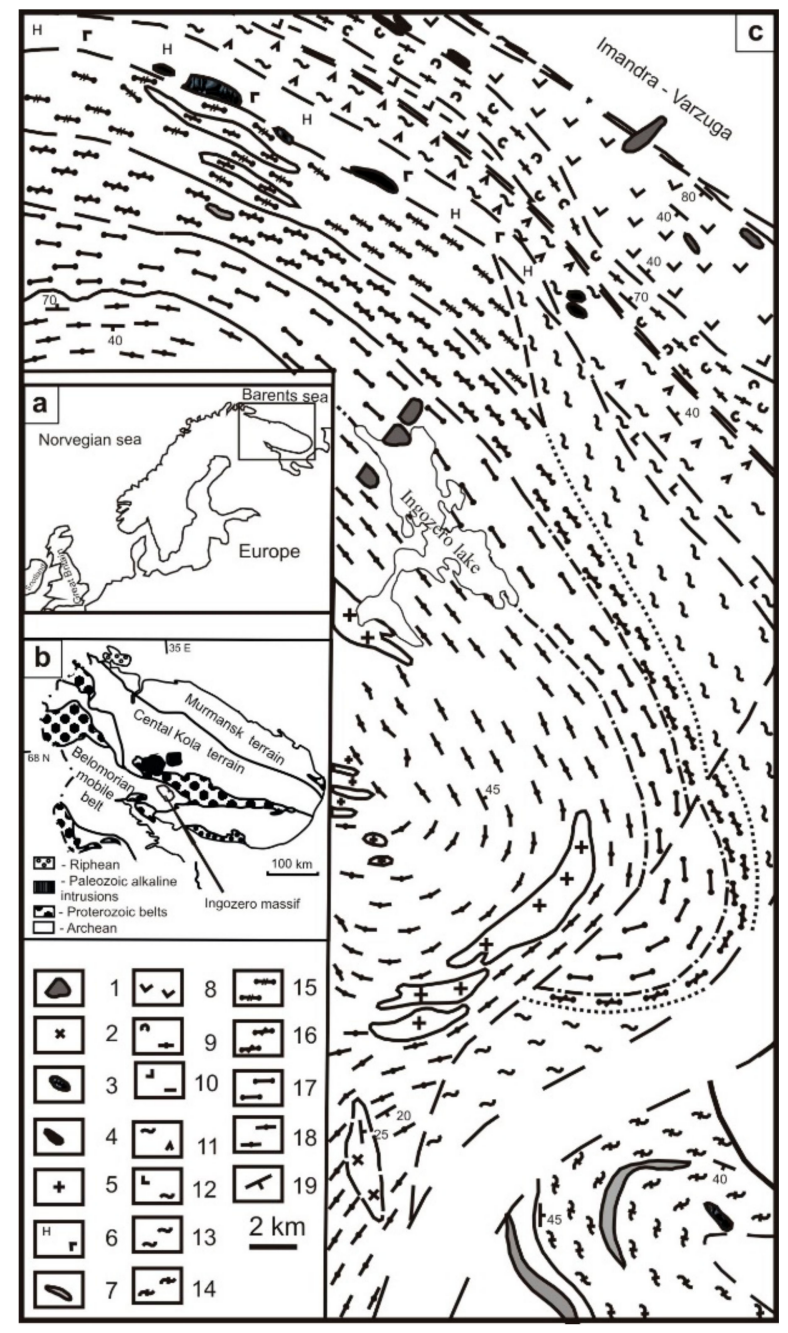

Figure 1. (a) NW Baltic Shield; (b) geological scheme of the Kola Peninsula [4]; (c) local geological map of the Ingozero massive [5], as amended by the authors. 1-peridotites, augite pyroxenites, ijolites; 2-arfvedsonite Aegirine Granites, Porphyry Granites; 3-granodiorites, plagioporphyrites; 4-plagioamphibolites; 5-aplitic granites; 6-gabbro-norites, norites; 7-(gabbro) amphibolites; 8-picritic metaporphyrites, phyllite schists, arkose metasandstones; 9-siltstone schists, including carbon-sulfide, metapelites, dolomites, limestones, volcanics of basic and secondary composition; 10-metadiabases, picritic metaporphyres; 11-volcanic and sedimentary shales; 12 -amphibolites, shale amphibolites, sometimes granitized; 13-biotite and biotite muscovite gneisses; 14-biotite muscovite gneisses, biotite, garnet-biotite gneisses; 15-biotite muscovite gneisses with amphibole; 16-amphibole gneisses and gneiss granites; 17-amphibole, biotite-amphibole gneisses; 18-biotite, amphibole-biotite gneisses gneiss; 19-bedding elements.

The Pechenga Region is situated in the Central Kola terrain (Figure 2, [14]) and composed of granite-gneisses with relics of biotite-plagioclase, biotite-amphibole-plagioclase, garnet-biotite-plagioclase gneisses, amphibolite, and iron quartzite [2,7]. The rocks are metamorphosed under the amphibolite and granulite facies of metamorphism [15,16]. The age of the earliest metamorphism of the Kola series is $2.8 \mathrm{Ga}$, the age of the last metamorphism is $2.7 \mathrm{Ga}[17,18]$, 
and the age of the protolith from gneisses is $2.9 \mathrm{Ga}[16,18]$. The garnet-biotite gneisses are the most ancient rocks in the Pechenga frame area by the structural-metamorphic scale [7], with iron quartzites (quartz metasomatites) forming along their contact with the metagabbro. Also, granodiorites with the age of $2722 \pm 9$ Ma [19] occur within the Malonemetskaya Bay exposure, cut by pegmatite veins.

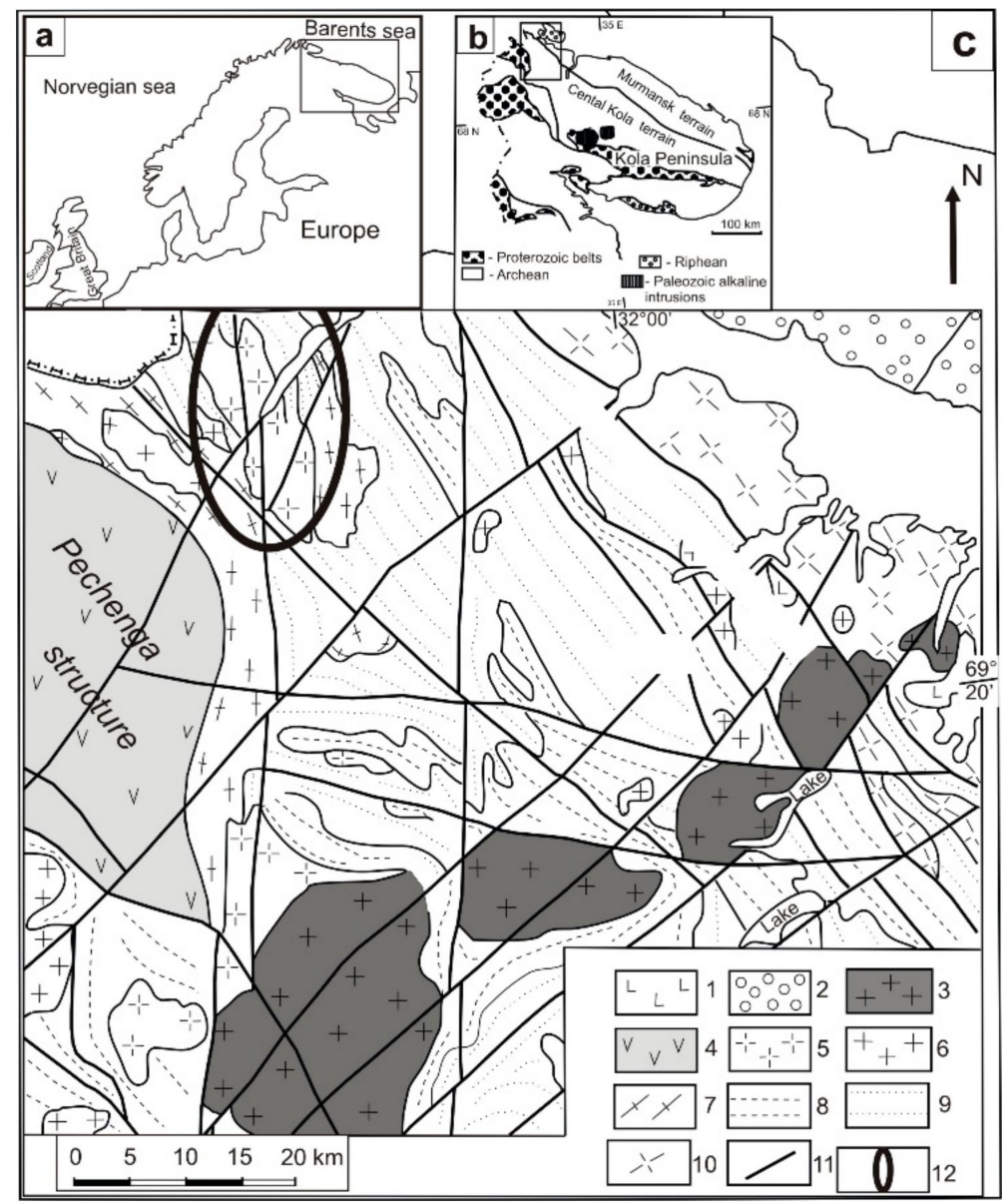

Figure 2. (a) NW Baltic Shield; (b) geological overview of the Kola Region, showing the locations of the Litsa area [2]; (c) local geological map of the Litsa area [14], as amended by the authors. 1,2-Riphean: 1-gabbro-dolerites and dolerites of the Murmansk complex, 2-sandstones, siltstones, and mudstones of the Kil'da Group; 3-5-Lower Proterozoic: 3-granite-granodiorites of the Litsa-Araguba complex, 4-volcanosedimentary rocks of the Pechenga Group, 5-granites of the Kaskel'javr complex; 6-10-Upper Archaean: 6-granites of the Voron'ya complex, 7-diorite-plagiogranites of the Porojarvi complex; 8,9-gneisses of the Kola Group: 8-amphibole-biotite, 9-high-alumina and garnet-biotite; 10-Lower Archaean: tonalites and plagiogranites; 11—faults; 12-fieldwork area.

The ancient metamorphic rocks developed at the northwestern margin of the Pechenga structure in the Central Kola terrain [4] are the basement for both the Pechenga ore and the Litsevsky uranium ore regions (Figure 2). The study of the terrain characterized by the wide development of iron ore formations is of interest for understanding their genesis. There are several theories of the iron quartzites' origin, including sedimentary [20], metasomatic [21], and synergistic [22] explanations of their formation. Earlier $[7,23]$, these rocks were considered to be homologs of rocks discovered by the Kola superdeep borehole, and thus the studied area was mapped in detail. The necessity to study them arose in connection with the interest to the nearby Lyceum Uranium ore region composed of similar rocks.

The aim of the present research is to determine the age sequence of the geological processes for the Ingozero massif and Pechenga frame rocks. 


\section{Materials and Methods}

\section{1. $\mathrm{U}-\mathrm{Pb}$ Method}

Various zircon grains and generations were selected from monomineral fractions. Morphological types of the zircon crystals were distinguished by the following features: appearance, habit, length-to-width ratio of crystals, color, and transparency. Zircon generations were identified during the study of the internal structure of the crystals, such as zonality, cores, and shells, as well as the development of forms of crystals during their growth [24]. Zircons were separated from the samples by using standard heavy liquid and electromagnetic techniques. Isotopes of lead and uranium were further extracted from each sample according to the method [25]. The selected grains were washed in $4 \mathrm{~N}$ (normal) $\mathrm{HNO}_{3}$ and repeatedly rinsed with $\mathrm{H}_{2} \mathrm{O}$ and acetone. The U-Pb analytical procedures followed the method of Krogh [25]. The zircons were digested at $205-210^{\circ} \mathrm{C}$ for $1-10$ days in $48 \% \mathrm{HF}$ in small stainless-steel jacketed Teflon bombs. The samples were evaporated to dryness and a few drops of $3.1 \mathrm{~N} \mathrm{HNO}_{3}$ were added and the samples were heated at $130{ }^{\circ} \mathrm{C}$ for $8-10 \mathrm{~h}$. The samples were then dissolved in $3.1 \mathrm{~N} \mathrm{HCl}$, and the solution was split into two aliquots for the measurement of $\mathrm{Pb}$ isotopic composition and $\mathrm{U}$ and $\mathrm{Pb}$ concentrations, using a mixed ${ }^{208} \mathrm{~Pb}+{ }^{235} \mathrm{U}$ tracer. $\mathrm{Pb}$ and $\mathrm{U}$ were extracted by $\mathrm{HCl}$ chemistry on fluoroplastic columns, using anion AG 1X8 (DowEuropeGmbH, Fombio, Italy) (200-400 mesh) resin. Total procedural blanks were less than $0.1 \mathrm{ng}$ for $\mathrm{Pb}$ and $0.01 \mathrm{ng}$ for $\mathrm{U}$.

$\mathrm{U}$ and $\mathrm{Pb}$ isotope measurements were done in the Laboratory of Geochronology of Geological Institute, Kola Science Center, Russia Academy of Science (GI KSC RAS). Pb and U were loaded together on outgassed single Re filaments with $\mathrm{H}_{3} \mathrm{PO}_{4}$ and silica gel. The temperatures of measurement were $1300^{\circ} \mathrm{C}$ for $\mathrm{Pb}$ and $1500{ }^{\circ} \mathrm{C}$ for U in the Laboratory of Geochronology of GI KSC RAS. The measurements were done on a multicollector Finnigan-MAT 262 and MI-1201T mass spectrometers. The Pb isotope ratios were corrected for mass fractionation with a factor of $0.10 \%$ per amu (Finnigan MAT-262) and $0.18 \%$ per amu (MI-1201T). The $\mathrm{U}$ analyses were corrected for mass fractionation with a factor of $0.003 \%$ per amu (Finnigan MAT-262) and $0.08 \%$ per amu (MI-1201T). Reproducibility of the U-Pb ratios was determined from the repeated analysis of standard zircon IGFM-87 (Ukraine) and is $0.56 \%$ for ${ }^{207} \mathrm{~Pb} /{ }^{235} \mathrm{U}$ and $0.50 \%$ for ${ }^{206} \mathrm{~Pb} /{ }^{238} \mathrm{U}$ at the $95 \%$ confidence level. The ages were calculated based on the accepted values of the uranium decay constants [26], and all errors were reported at the $2 \sigma$ level. The isochrones parameters were calculated by the PBDAT and ISOPLOT programs [27,28]. The correction needed for the non-radiogenic lead impurity was done, using the model [29].

\subsection{Sm-Nd Method}

Samples for $\mathrm{Sm}-\mathrm{Nd}$ analysis were treated using the ordinary techniques: dissolution in $\mathrm{HF}+\mathrm{HNO}_{3}$ (or $+\mathrm{HClO}_{4}$ ) in Teflon beakers at $100{ }^{\circ} \mathrm{C}$ with following extraction of $\mathrm{Sm}$ and $\mathrm{Nd}$ by ion-exchange column chromatography. $\mathrm{Nd}$ and $\mathrm{Sm}$ were measured by the isotopic dilution technique with a mixed ${ }^{149} \mathrm{Sm} /{ }^{150} \mathrm{Nd}$ tracer on double Re + Re filaments on multicollector Finnigan-MAT 262 mass spectrometer. ${ }^{143} \mathrm{Nd} /{ }^{144} \mathrm{Nd}$ ratios were normalized to ${ }^{146} \mathrm{Nd} /{ }^{144} \mathrm{Nd}=0.7219$. The mean value for the ${ }^{143} \mathrm{Nd} /{ }^{144} \mathrm{Nd}$ obtained for the La Jolla standard was $0.511857 \pm 7(2 \sigma, n=8)$. A minimum error of $0.003 \%$ was chosen based on the reproducibility of the La Jolla standard. The uncertainty in the ${ }^{147} \mathrm{Sm} /{ }^{144} \mathrm{Nd}$ ratios is the average of 7 measurements in the BCR standard and is equal to $0.2 \%(2 \sigma)$. $\mathrm{Nd}$ blanks were less than $0.3 \mathrm{ng}$, and Sm blanks were less than $0.06 \mathrm{ng}$.

\subsection{Geological Setting and Sampling}

The Kola region is situated in the northeastern part of the Baltic Shield (Figure 1a,b) consisted of Murmansk, Belomorian, Tersky, Keivy, and Inari terrains, such as Yona and Kolmozero-Voronja Archean greenstone belts; and Lapland, Kandalaksha-Kolvitsa granulite belts; and Pechenga, Imandra-Varzuga Early Proterozoic zone $[4,30]$.

The Pechenga frame outcrops are situated in the northwestern part of the Murmansk terrain, which is composed of tonalites, plagiogranites, granodiorites and enderbites, and of an intrusion 
complex of diorite-plagiogranite, anatectite-granite, enderbite-granite, palingenetic-metasomatic, and subalkaline granites associations of different ages [18]. The Murmansk terrain was formed apparently in the Late Archean, and its partial destructuring took place in the Early Proterozoic.

The Ingozero massive belong to the Belomorian mobile belt consisted largely of Late Archean dome-fold and complex-fold structures reworked in the Early Proterozoic. For the most part, the domain area is composed of granite-gneisses, migmatites, and gneisses containing amphibolite bodies $[13,30]$.

\subsection{Ingozero Massif}

The Ingozero massif consists of biotite, biotite-amphibole, amphibole-biotite gneisses, amphibolites, granites, granodiorites, and pegmatites $[2,3,6,8,9]$. The gneisses are metamorphosed TTG rocks and have similar azimuths and dip angles in all outcrops of the Ingozero complex [7]. The mafic dikes metamorphosed together with the gneisses are now the feldspar amphibolites and cut by coarse-grained granites and pegmatite veins. The medium-grained massive light-gray granites contain pegmatite porphyries and form small thickness veins intruded the gneisses, with the granites cut by pegmatite veins. The quartz veins breaking through gneisses and pegmatite are also observed.

The outcrop "Exposure No. 8" consists of biotite-amphibole gneisses, plagiogranite, pegmatite, and pegmatitic veins (Figure 3). The gneisses are the remnants of the initial rocks metamorphosed and strongly affected by granitization and have the dip azimuth of $30^{\circ}$ and dip angle of $33^{\circ}$. The contacts between the gneisses, the plagiogranite, and the pegmatite are sharp. There are two pegmatite veins with northeastern and northern strike. Both veins have small thickness and cut the gneisses and granite. Samples of the biotite-amphibole gneiss (H-0-06) and the plagiogranite (N-10-05) were picked in the outcrop.

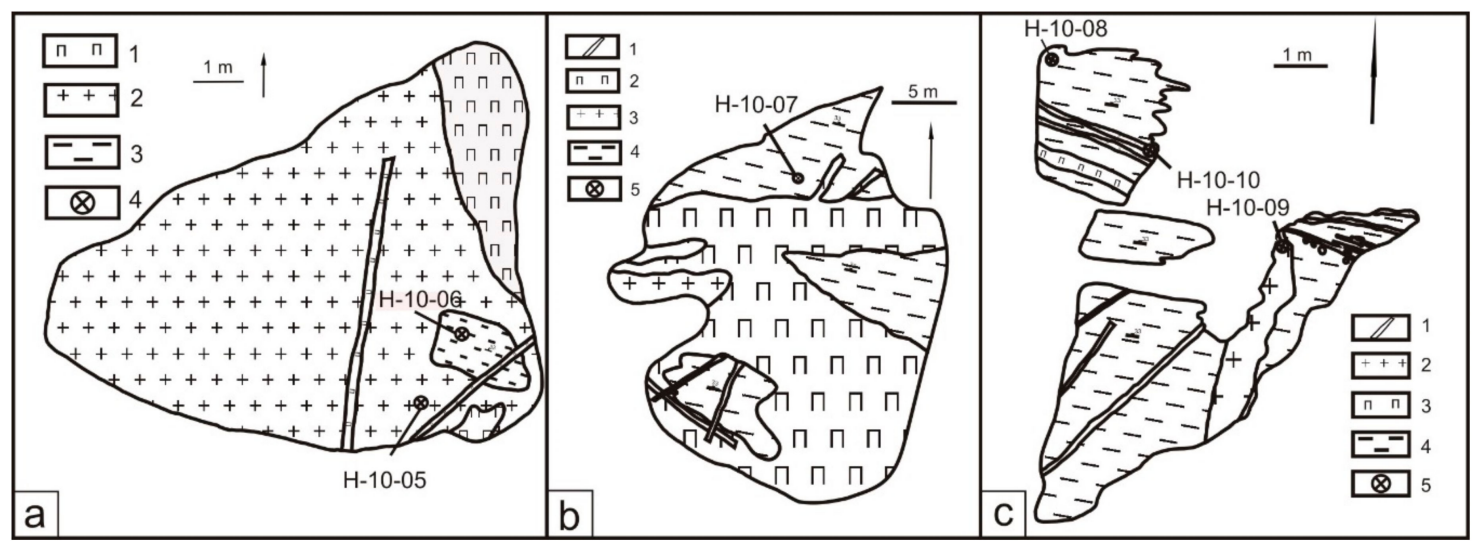

Figure 3. Geology of the Ingozero massive outcrops: (a) geological scheme of the "Exposure 8". 1-pegmatites, 2-plagiogranites, 3-biotite-amphibole gneisses, 4-sampling points; (b) geological scheme of the "Exposure 9". 1-quartz veins, 2-pegmatites, 3-plagiogranites, 4-amphibole-biotite gneisses, 5-sampling points; (c) geological scheme of the "Exposure 10". 1-quartz veins, 2-granite veins, 3-pegmatites, 4-biotite-amphibole gneisses, 5-sampling points.

The outcrop "Exposure No. 9" composed of amphibole-biotite gneisses, plagiogranite, pegmatite, and quartz veins (Figure 3). The gneisses have the dip azimuth of $30^{\circ}$ and dip angle of $33^{\circ}$ and are cut with the granites by the pegmatites. Samples of the amphibole-biotite gneisses (N-10-07) were picked in the outcrop.

The outcrop "Exposure No. 10" consists of biotite-amphibole gneisses, pegmatite, a granite vein, and quartz veins (Figure 3). The gneisses have the dip azimuth of $30^{\circ}$ and dip angle of $33^{\circ}$ and pegmatite layers and are cut by the granites and quartz veins. Samples of the biotite-amphibole gneisses (H-0-08), the pegmatite (H-10-10), and the granite vein (N-10-09) were picked in the outcrop. 


\subsection{Pechenga Frame}

The structural, metamorphic, and geochronological studies were carried out in three outcrops, i.e., the Polygon, the Pereval, and the Malonemetskaya Bay.

The Polygon outcrop consists of gray granites and garnet-biotite gneisses with staurolite-garnet-biotite gneisses layers (Figure 4). Thickness of the granite layers is $15-40 \mathrm{~m}$. Thickness of the garnet-biotite gneisses varies from 15 to $50 \mathrm{~m}$. There are garnet-biotite gneisses lenses of $3 \mathrm{~m}$ thick inside the plagiogranite in the outcrop central part. Silicification zones of these gneisses and the quartz veins are located among the garnet-biotite gneisses. It is proposed that the gneiss silicification is associated with the granitization process and the silicification zones are zones where the most intensely tectonic processes appeared. The pegmatite veins have a northwestern strike and cut the gneisses. The thickness of the pegmatite varies from 1.5 to $2 \mathrm{~m}$. The garnet-biotite gneisses (sample VII-12 kg) were collected in the southern part of the outcrop.

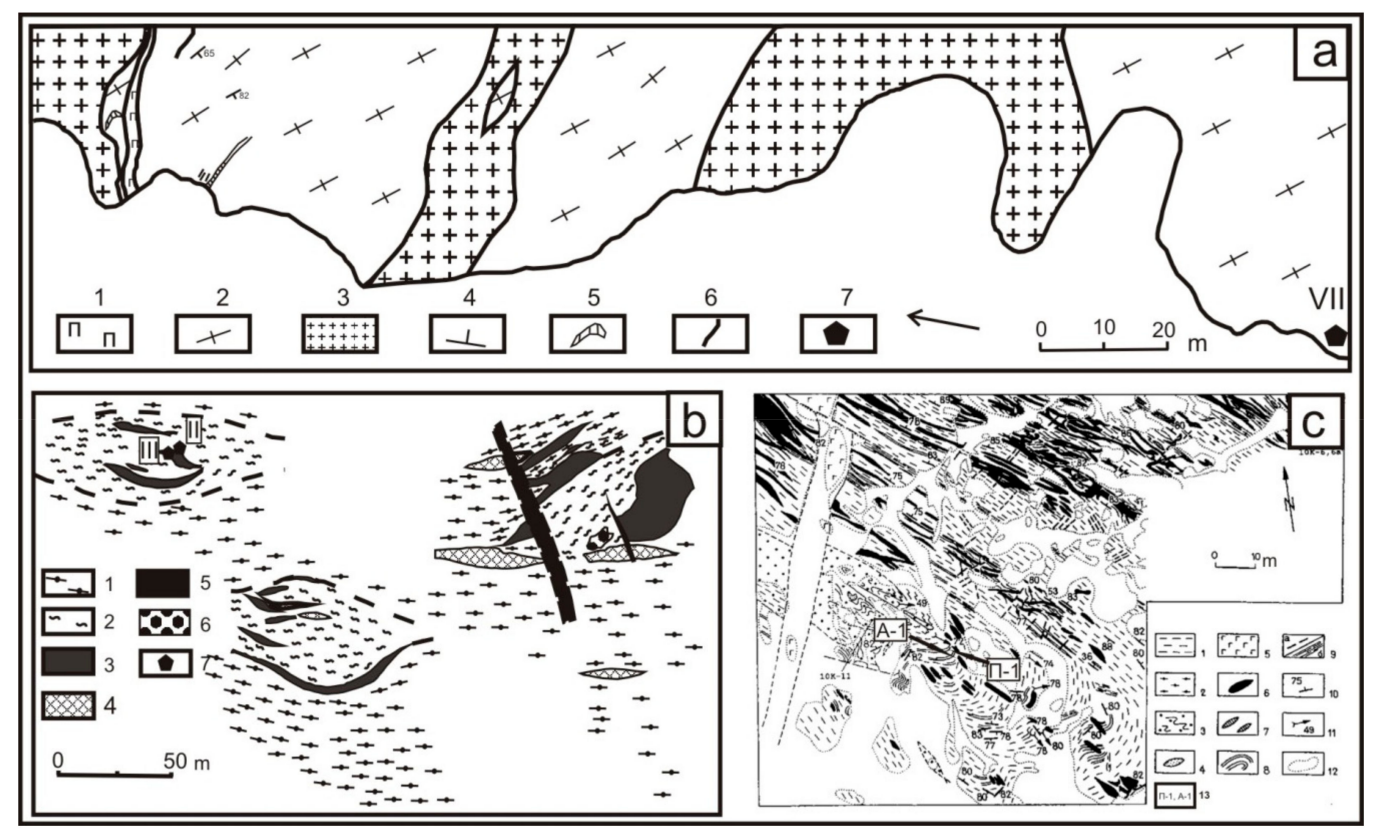

Figure 4. Geology of the Pechenga frame outcrops: (a) geological scheme of the Polygon outcrop. 1-pegmatites, 2-garnet-biotite gneisses, 3-plagiogranites, 4-elements of rock occurrences, 5-silicification zones, 6-quartz veins, 7-sampling points; (b) geological scheme of the Pereval outcrop. 1-biotite-amphibole gneisses, 2-metagabbro, 3-iron quartzites, 4-granodiorites, 5-dolerites, 6-garnet amphibolites, 7-sampling points; (c) structural-geological map of the Malonemezkaya Bay Area. 1-Biotite-amphibole gneisses, 2-iron quartzites, 3-iron quartzites and garnet amphibolites, 4-granitites, 5-metagabbro, 6-plagiomicrocline pegmatites, 7-quartz veins, 8-aplite veins with amphibole, 9-faults, 10-elements of the foliation and metamorphic banding occurrence, 11—shear fold hinges, 12-boundaries between rock varieties, 13-sampling points.

The garnet-biotite and biotite gneisses located within the Pereval outcrop have a sublatitudinal stretching (Figure 4). Metamorphosed and boudinaged gabbros (metagabbro) is located parallel to the gneiss foliation and cut by the aplites. The quartz-pyroxene and quartz-amphibole metasomatic rocks with garnet and without one (iron quartzite) are located along the contact of the feldspar amphibolites and garnet-biotite gneisses. The granite boudinaged bodies are situated along the strike of the shale-like garnet-biotite and biotite gneisses. The metadolerite dikes are the youngest rock in the outcrop, with sublatitudinal and submeridional strike. The metagabbro (sample II-27.7 kg) and the iron quartzite (sample III-25.3 kg I) were selected in the northwestern part of the outcrop in the central part of the boudinaged metagabbro. 
The Malonemetskaya Bay outcrop contains biotite-amphibole and biotite gneisses with beds of the banded iron formation (Figure 4). The gneisses were metamorphosed under amphibolite and epidote-amphibolite facies of metamorphism, while the surrounding garnet-biotite and alumina gneisses were metamorphosed under amphibolite to granulite facies. The aplite and pegmatite veins cut all the rocks of the outcrop. The granodiorite occurs at the Malonemetskaya Bay with an age of $2722 \pm 9 \mathrm{Ma}$ [19]. The aplite (sample A-1 - $2.5 \mathrm{~kg}$ ) and the pegmatite (sample P-1 $-3.2 \mathrm{~kg}$ ) were selected at the central part of the outcrop.

\section{Results}

\subsection{Endogenous Processes Sequence and Deformation Stages, Sample Geochemistry, and Petrography}

\subsubsection{Ingozero Massif}

The endogenous processes sequence of the Ingozero massif [7] includes the following stages: (1) formation of the gneiss initial rocks; (2) mafic dikes intrusion metamorphosed and deformed to feldspar amphibolites in the next stage; (3) deformation and schistosity of the rocks; (4) the granite emplacement and the biotite gneisses microclinization forming pegmatite veins according to the shale; (5) the wide spreading of pegmatite, the gneisses xenoliths preserve the initial azimuths and dip angles (are not transformed or turned); (6) pegmatite and granite veins occurrence; and (7) quartz veins formation.

Biotite, amphibole-biotite, and biotite-amphibole gneisses are composed of quartz + plagioclase + biotite + microcline \pm amphibole; accessory minerals are zircon, calcite, zoisite, and epidote; the secondary mineral is sericite (Figure $5 \mathrm{a}-\mathrm{c}$ ). The plagiogranite consists of quartz + plagioclase + biotite + microcline \pm amphibole; accessory minerals are garnet, zircon, zoisite, and titanite; and the secondary mineral is sericite (Figure $5 \mathrm{~d}$ ). The pegmatite composition is quartz \pm plagioclase \pm microcline; the secondary mineral is sericite (Figure 5e). The granite veins consist of quartz + plagioclase + biotite + microcline \pm amphibole; accessory minerals are garnet, zircon, zoisite, and titanite, and the secondary mineral is sericite (Figure $5 \mathrm{f}$ ).

Table 1 [31] shows the rock chemical compositions. According to the reconstruction data of the primary nature of the gneisses by A. A. Predovskiy [32], all the studied samples fell into the field of igneous rocks. The Ingozero gneisses are characterized by high contents of $\mathrm{Na}$ and $\mathrm{Ca}$ and low $\mathrm{K}$, and the data points of the chemical analysis of the gneisses are in the fields of tonalites and trondjemites (Figure 6) on the $\mathrm{Ab}-\mathrm{An}-\mathrm{Or}$ diagram [33]. The gneisses are characterized by high contents of light rare-earth elements ( $\mathrm{La}, \mathrm{Ce}$, and $\mathrm{Pr}$ ) with a steep drop in the REE distribution curve (from La to Dy) and subsequent flattening to Lu at a low content of heavy REE (Figure 7, [34]).

The high content of light rare-earth elements and the absence of the Eu anomaly indicate that the rocks originated from enriched sources, without the significant role of fractional crystallization. Moreover, the distribution of rare-earth elements is similar to that for rocks of TTG complexes found all over the world in Precambrian Shields [35]. The plagiogranites are characterized by the high K and low Ca concentration. There is a gradual decrease from light to heavy element concentrations, and the positive Eu anomaly in the distribution of rare-earth elements (Figure 7).

The temperatures of the granitoid melt crystallization were calculated by using the zircon saturation thermometer [36] for the biotite gneisses (H-10-01), the amphibole-biotite gneisses (H-10-07), the biotite-amphibole gneisses (H-10-08), and the plagiogranites (H-10-05). The calculated $\mathrm{Zr}$ saturation temperature for granites containing xenogenic zircon cores is close to the crystallization temperatures of acid melt; however, the estimating temperatures for granites devoid of xenogenic zircons are less than the melt temperatures [37]. Thus, the temperature of the granitoid melts from the Ingozero massif was $\sim 750^{\circ} \mathrm{C}$, and of the granite veins temperature was more than $670{ }^{\circ} \mathrm{C}$. 

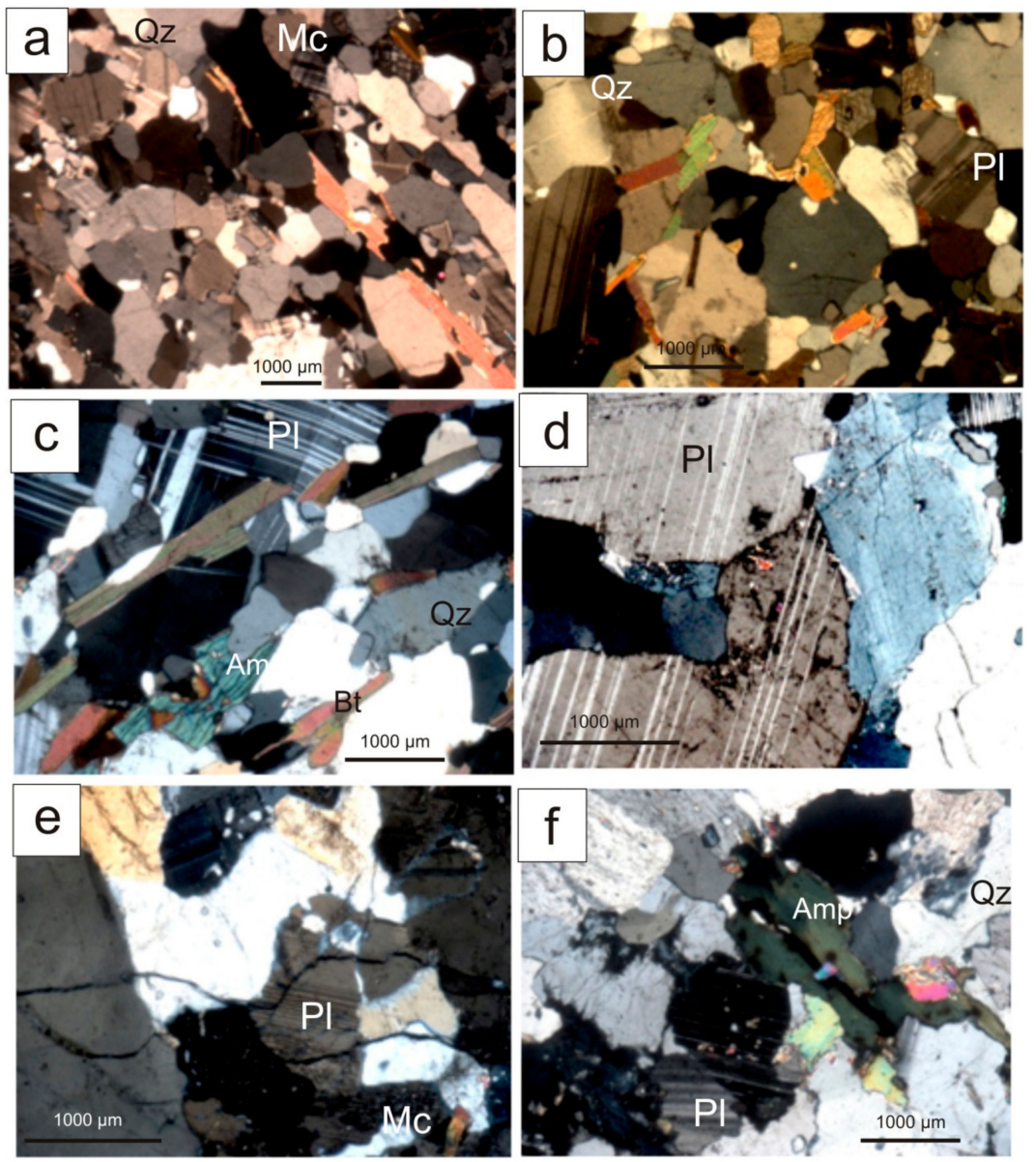

Figure 5. Photos of the sample thin sections (crossed nicols):

(a) - biotite gneisses, (b) - biotite-amphibole gneisses, (c)—amphibole-biotite gneisses, (d)—plagiogranites, (e)—pegmatites, and (f)—granites. Explanations for mineral abbreviations: Pl—plagioclase, Mc-microcline, Qz-quartz, Amp—amphibole, Bt—biotite.

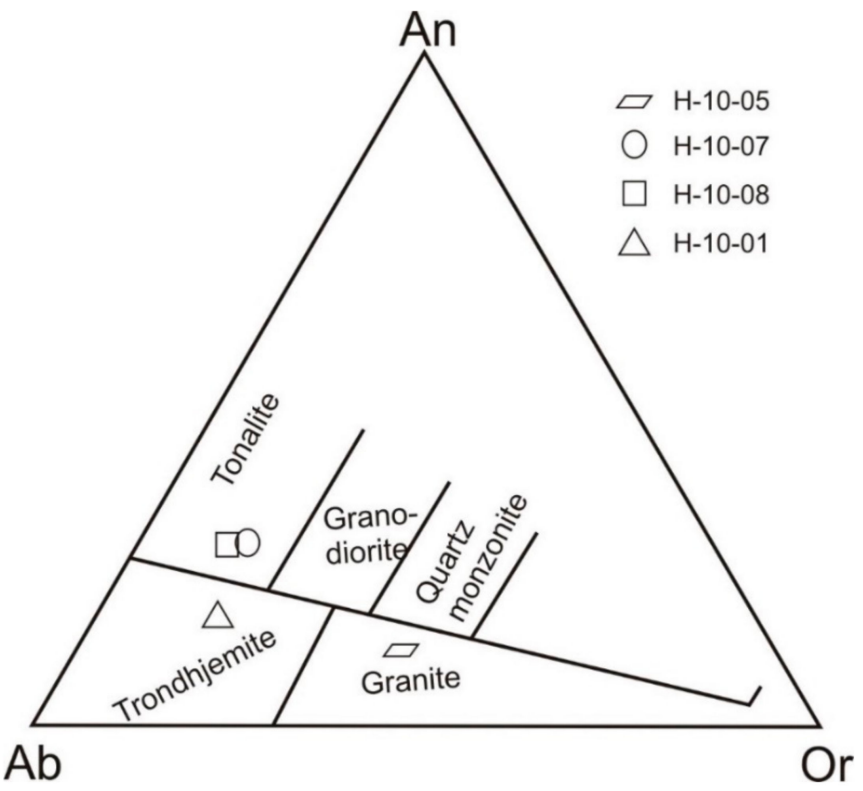

Figure 6. Ab-An-Or diagram [33] for biotite gneisses (H-10-01), amphibole-biotite gneisses (H-10-07), biotite-amphibole gneisses (H-10-08), and plagiogranites (H-10-05) of the Ingozero massif TTG complex. 
Table 1. Chemical composition of the Ingozero massif gneisses and granites.

\begin{tabular}{|c|c|c|c|c|c|c|c|}
\hline Oxides (\%) & H-10-01 & H-10-05 & H-10-07 & H-10-08 & H-10-06 & H-10-09 & H-10-10 \\
\hline $\mathrm{SiO}_{2}$ & 71.12 & 73.5 & 67.81 & 66.55 & 73.01 & 73.22 & 68.25 \\
\hline $\mathrm{TiO}_{2}$ & 0.26 & 0.20 & 0.49 & 0.47 & 0.14 & 0.06 & 0.04 \\
\hline $\mathrm{Al}_{2} \mathrm{O}_{3}$ & 14.22 & 12.15 & 13.90 & 13.85 & 13.06 & 13.96 & 16.78 \\
\hline $\mathrm{Fe}_{2} \mathrm{O}_{3}$ & 0.22 & 0.93 & 0.11 & 1.09 & 0.00 & 0.00 & 0.00 \\
\hline $\mathrm{FeO}$ & 2.94 & 3.27 & 4.77 & 4.40 & 3.13 & 1.64 & 1.71 \\
\hline $\mathrm{MnO}$ & 0.037 & 0.036 & 0.075 & 0.059 & 0.03 & 0.02 & 0.08 \\
\hline $\mathrm{MgO}$ & 0.65 & 0.27 & 1.69 & 2.00 & 0.16 & 0.04 & 0.04 \\
\hline $\mathrm{CaO}$ & 2.46 & 1.29 & 3.95 & 4.29 & 1.28 & 0.45 & 0.64 \\
\hline $\mathrm{Na}_{2} \mathrm{O}$ & 5.20 & 3.34 & 4.13 & 4.26 & 3.57 & 4.39 & 5.13 \\
\hline $\mathrm{K}_{2} \mathrm{O}$ & 1.70 & 3.93 & 1.37 & 1.32 & 4.45 & 4.99 & 6.06 \\
\hline $\mathrm{S}$ & 0.07 & 0.12 & 0.12 & 0.15 & 0.09 & 0.08 & 0.09 \\
\hline $\mathrm{F}$ & 0.025 & 0.007 & 0.054 & 0.050 & 0.009 & 0.004 & 0.005 \\
\hline $\mathrm{Cl}$ & $<0.004$ & 0.007 & 0.005 & 0.005 & 0.007 & 0.007 & 0.006 \\
\hline $\mathrm{P}_{2} \mathrm{O}_{5}$ & 0.07 & $<0.01$ & 0.10 & 0.09 & 0.02 & 0.01 & 0.01 \\
\hline $\mathrm{Li}_{2} \mathrm{O}$ & 0.0055 & 0.0065 & 0.023 & 0.014 & 0.0058 & 0.0016 & 0.0017 \\
\hline $\mathrm{Rb}_{2} \mathrm{O}$ & 0.0056 & 0.0094 & 0.0072 & 0.0061 & 0.012 & 0.017 & 0.021 \\
\hline $\mathrm{Cs}_{2} \mathrm{O}$ & 0.00016 & 0.00018 & 0.00027 & 0.00024 & 0.00011 & 0.00023 & 0.00026 \\
\hline $\mathrm{CO}_{2}$ & 0.54 & 0.48 & 0.26 & 0.34 & 0.07 & 0.00 & $<0.01$ \\
\hline $\mathrm{Cr}_{2} \mathrm{O}_{3}$ & 0.008 & 0.105 & 0.018 & 0.089 & 0.006 & 0.04 & 0.03 \\
\hline $\mathrm{Cu}$ & $<0.005$ & $<0.005$ & 0.005 & 0.005 & $<0.01$ & $<0.01$ & $<0.01$ \\
\hline Co & $<0.01$ & $<0.01$ & $<0.01$ & $<0.01$ & 0.002 & 0.006 & 0.002 \\
\hline $\mathrm{Ni}$ & 0.005 & 0.006 & 0.007 & 0.008 & $<0.01$ & $<0.01$ & 0.010 \\
\hline $\mathrm{Zn}$ & 0.011 & 0.005 & 0.008 & 0.008 & $<0.01$ & $<0.01$ & $<0.01$ \\
\hline Elements (ppm) & \multicolumn{2}{|c|}{ H-10-01 * [31] } & H-10-05 * [31] & \multicolumn{2}{|c|}{ H-10-07 * [31] } & \multicolumn{2}{|c|}{ H-10-08 * [31] } \\
\hline $\mathrm{Cr}$ & \multicolumn{2}{|c|}{87} & 803 & \multicolumn{2}{|c|}{231} & \multicolumn{2}{|c|}{695} \\
\hline $\mathrm{Ni}$ & \multicolumn{2}{|c|}{20} & 35 & \multicolumn{2}{|c|}{47} & \multicolumn{2}{|c|}{60} \\
\hline $\mathrm{Rb}$ & \multicolumn{2}{|c|}{51} & 97 & \multicolumn{2}{|c|}{67} & \multicolumn{2}{|c|}{53} \\
\hline $\mathrm{Sr}$ & \multicolumn{2}{|c|}{353} & 215 & \multicolumn{2}{|c|}{253} & \multicolumn{2}{|c|}{313} \\
\hline $\mathrm{Y}$ & \multicolumn{2}{|c|}{3.5} & 1.89 & \multicolumn{2}{|c|}{10.1} & \multicolumn{2}{|c|}{7.8} \\
\hline $\mathrm{Zr}$ & \multicolumn{2}{|c|}{124} & 36 & & & & \\
\hline $\mathrm{Nb}$ & & & 6.5 & & & & \\
\hline Cs & & & 1.36 & & & & \\
\hline $\mathrm{Ba}$ & & & 508 & & & & \\
\hline $\mathrm{La}$ & & & 4.2 & & & & \\
\hline $\mathrm{Ce}$ & & & 7.8 & & & & \\
\hline $\mathrm{Pr}$ & & & 0.91 & & & & \\
\hline $\mathrm{Nd}$ & & & 3.3 & & & & \\
\hline $\mathrm{Sm}$ & & & 0.60 & & & & \\
\hline $\mathrm{Eu}$ & & & 0.39 & & & & \\
\hline $\mathrm{Gd}$ & & & 0.62 & & & & \\
\hline $\mathrm{Tb}$ & & & 0.085 & & & & \\
\hline Dy & & & 0.48 & & & & \\
\hline Ho & & & 0.082 & & & & \\
\hline $\mathrm{Er}$ & & & 0.18 & & & & \\
\hline $\mathrm{Tm}$ & & & 0.027 & & & & \\
\hline $\mathrm{Yb}$ & & & 0.16 & & & & \\
\hline $\mathrm{Lu}$ & & & 0.027 & & & & \\
\hline Hf & & & 1.33 & & & & \\
\hline $\mathrm{Ta}$ & & & 0.62 & & & & \\
\hline Th & & & 5.8 & & & & \\
\hline $\mathrm{U}$ & & & 2.4 & & & & \\
\hline
\end{tabular}




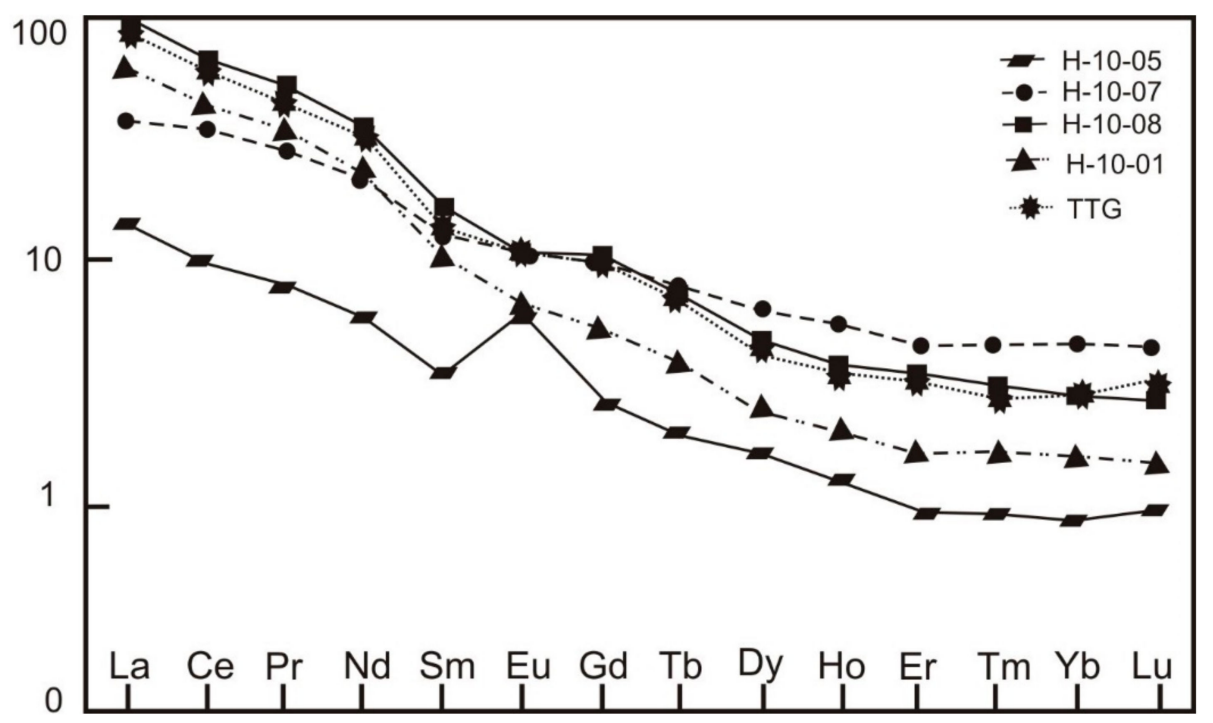

Figure 7. Chondrite normalized REE pattern [34] for biotite gneisses (H-10-01), amphibole-biotite gneisses (H-10-07), biotite-amphibole gneisses (H10-08), and plagiogranites (H-10-05) of the Ingozero massif TTG complex (chemical analysis by IGM SB RAS).

\subsubsection{Pechenga Frame}

The endogenous processes and deformation sequence are determined by the following stages. The original alternation of biotite, garnet-biotite, and staurolite-garnet-biotite gneisses is considered to be preliminary banding. Shale, fine, and coarse migmatite banding occurred during the first deformation stage. During the second stage, the migmatite banding was wrinkled into folds, and pegmatite intruded parallel to the axial planes. The gabbros were emplaced between the second and third stages of deformation. The granites intruded it during the third deformation stage; and the garnet-biotite, biotite gneisses, and gabbros were split and boudinaged together. The gabbros were transformed into amphibolites. The magnetite-silicate rocks were formed along the shear zones marking the boudings inside the bodies of the metamorphosed gabbro. The magnetite-quartz, magnetite-amphibole, and magnetite-pyroxene rocks were formed along the contact between the gabbros and gneisses. The coarse-grained pegmatites intruded after the third stage of deformation cutting the boundaries between amphibolite lenses. The coarse-grained microcline-containing aplites were formed, and gneiss, pegmatite, and granite deformated during the fourth stage. During the final stage, metadolerite dikes intruded through a network of sublatitudinal and submeridional cracks.

The garnet-biotite gneiss (VII) with a schistos texture and a lepidogranoblastic structure consist of (see Figure $8 \mathrm{a}, \mathrm{b}$ ) quartz $(40 \%)$ of $0.15-0.45 \mathrm{~mm}$ in size; biotite grains ( $20 \%$ ) with size $0.06-0.6 \mathrm{~mm}$, which formed a fine-flaked mass; plagioclase grains (20\%) with sizes ranging from 0.3 to $0.9 \mathrm{~mm}$, which are replaced by epidote and chlorite; garnet grains (10\%) from 0.6 to $3 \mathrm{~mm}$ in size replaced by chlorite and biotite; prismatic kyanite crystals $(3 \%)$ and staurolite $(3 \%)$, as well as muscovite $(3 \%)$; ore mineral (1\%); and zircon grains (individual) $0.03 \mathrm{~mm}$ in size.

The metagabbro (II) has massive texture and nematoblastic structure and consists of (Figure 8c) amphibole grains (85\%) ranging from 0.3 to $3 \mathrm{~mm}$ in size and colorless grains of plagioclase (15\%) from 0.2 to $0.25 \mathrm{~mm}$ in size.

The iron quartzite (III) with a schistose texture and granoblast structure consists of (Figure 8d) quartz grains $(60 \%)$ with sizes ranging from 0.3 to $3 \mathrm{~mm}$; elongated cummingtonite $(15 \%)$ replaced by amphibole near the ore mineral in some places; orthopyroxene grains $(10 \%)$ from 0.5 to $1.5 \mathrm{~mm}$ in size replaced by cummingtonite; ore mineral (5-10\%) formed at the contact between quartz and cummingtonite.

The fine-grained aplits (Figure 8e) with allotriomorphic structure consist of quartz $(40 \%)$, plagioclase (55\%), and biotite (5\%). 
The pegmatites (Figure 8f) have a porphyroblastic structure and consist of quartz (65\%) and plagioclase (35\%).
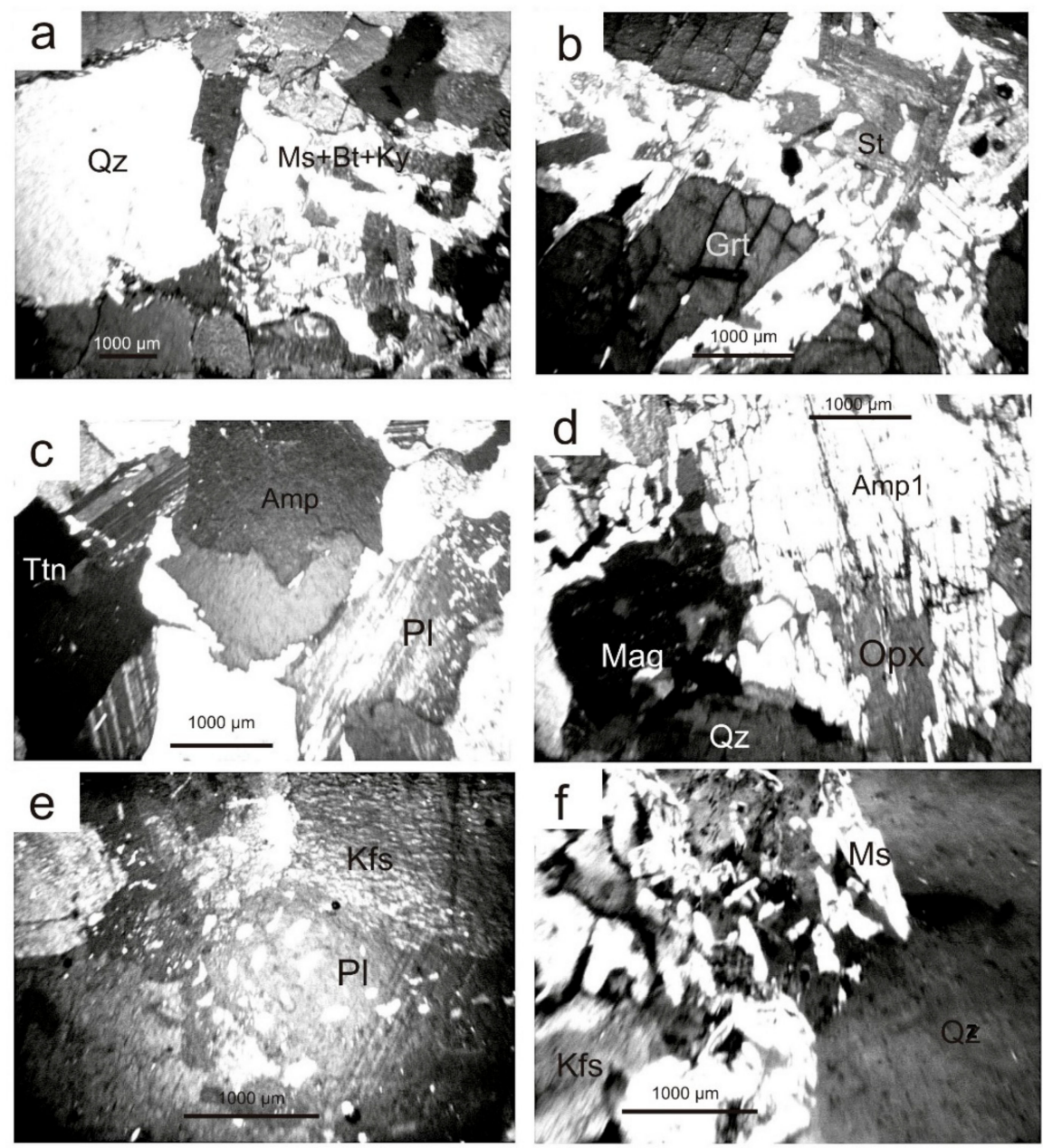

Figure 8. Photos of the sample thin sections (crossed nicols): (a,b)-garnet-biotite gneisses, (c) - metagabbro, (d) - iron quartzites, (e)—aplites, and (f) - pegmatites. Explanations for mineral abbreviations: $\mathrm{Pl}$-plagioclase, $\mathrm{Mc}$-microcline, Qz-quartz, Amp—amphibole, Bt—biotite.

\subsection{Zircon Mineralogy and $U-P b$ Dating}

\subsubsection{Ingozero Massif}

The zircon grains handpicked from the amphibole-biotite gneisses (H-10-07) are represented by slightly fissured dark- and light-brown transparent short- and long-prismatic crystals. For the $\mathrm{U}-\mathrm{Pb}$ dating zircon fractions were taken according to crystal morphology-The presence of prisms and dipyramids faces and the length-to-width ratio of crystals. One of the zircon fractions was dissolved by using a two-stage dissolution technique which allowed us to isolate the rims usually corresponding to the last metamorphism stage. It was made for the fraction (point 1) whose concordant age of $2667 \pm 7 \mathrm{Ma}$ was obtained. The other four zircon fractions provided the age of $2725 \pm 2 \mathrm{Ma}$ (Tables 2 and 3; Figure 9b). The zircons of the concordant data point are characterized by a low Th/U ratio equal to 0.06 . The previous dada provided the oldest $\mathrm{U}-\mathrm{Pb}$ age for magmatic protolith of the Ingozero gneisses in $3149 \pm 46 \mathrm{Ma}$ [10], and Sm-Nd model ages showed that the gneisses protolite initial melt formed at 3.1-2.8 Ga. Therefore, the age of $2667 \pm 7 \mathrm{Ma}$, which is close to the biotite gneiss age, we also interpret as the age of the TTG rock metamorphism, with transforming to amphibole-biotite gneisses. The age of $2725 \pm 2$ Ma possibly reflects the second stage of the tonalite emplacement, or the 
metamorphism stage associated with the mafic dikes' intrusion. The lower intercept of 614 Ma has no geological sense or reflects the cumulative effect of modern lead loss and some ancient geological events. The lower intercepts in this case do not correspond to any known event within NW Baltic Shield.
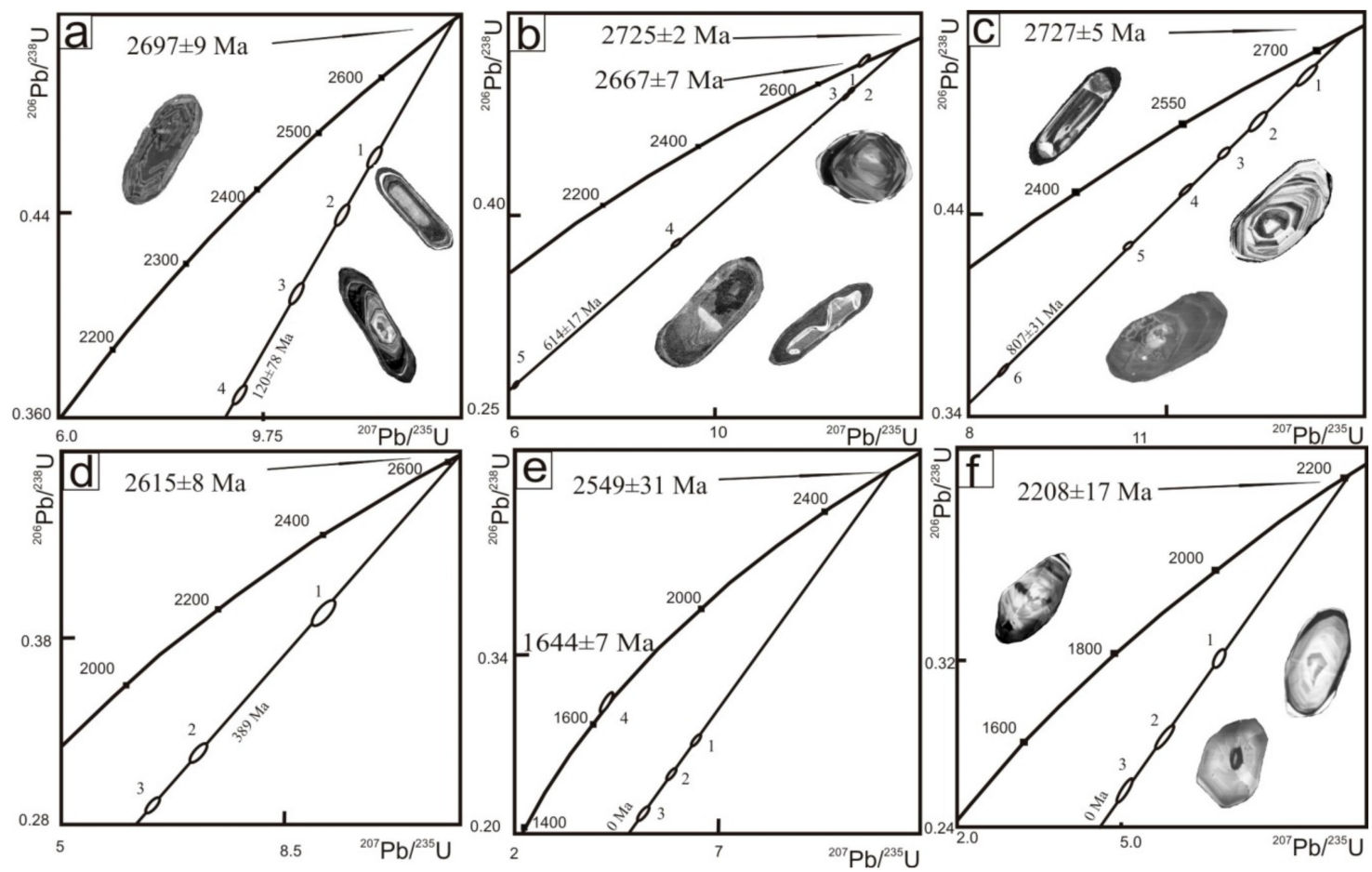

Figure 9. Concordia diagram for (a) biotite gneisses (H-10-01), (b) amphibole-biotite gneisses (H-10-07), (c) biotite-amphibole gneisses (H-10-08), (d) biotite-amphibole gneiss (H-10-06), (e) points 1-3-pegmatites (H-10-10), (e) point 4-granite veins (H-10-09), and (f) - plagiogranites (H-10-05).

The amphibole-biotite gneiss sample (H-10-01) was taken in the region of amphibole-biotite gneisses development from the eluvial-deluvial formation. Zircon grains selected from the biotite gneiss for $\mathrm{U}-\mathrm{Pb}$ dating, using the ID-TIMS method, are represented by slightly fractured dark-brown transparent prismatic and short-prismatic crystals. Zircon grains were handpicked by size fractions: $<0.075 \mathrm{~mm}$ - point 1 on the concordia diagram; $>0.15 \mathrm{~mm}$-point $2 ; 0.1-0.15 \mathrm{~mm}$-point 3; $0.075-0.1 \mathrm{~mm}$ - point 4 . The upper discordia intersected by four figurative points is $2697 \pm 9 \mathrm{Ma}$ (Table 3 and Figure 9a). The lower intercept of 120 Ma probably corresponds to zero, with some uncertainties. The zircons' high uranium contents of up to $828 \mathrm{ppm}$, and low Th/U ratios calculated from ${ }^{206} \mathrm{~Pb} /{ }^{208} \mathrm{~Pb}$ ratios equal to $0.11-0.15$ are characterized by magmatic zircon from granites opposite to the TTG [24]. The previous isotope $\mathrm{U}-\mathrm{Pb}$ dating of individual zircon grains from the biotite gneisses provided the oldest age for magmatic protolith of the Ingozero gneisses, which is $3149 \pm 46 \mathrm{Ma}$ [10]. Therefore, the age of $2697 \pm 9 \mathrm{Ma}$ is interpreted as the age of TTG rocks metamorphism and granitization, with TTG transforming to the gneisses probably during the granitoid emplacement.

The zircon grains from the granite-gneisses $(\mathrm{H}-10-08)$ are prismatic fractured and transparent crystals from brown to pale-pink in color. Six zircon fractions were picked and separated by color, elongation, and transparency of the grains and had the age of $2727 \pm 5 \mathrm{Ma}$ (Tables 2 and 3; Figure 9c). The $2727 \pm 5 \mathrm{Ma}$ age of the biotite-amphibole gneisses is similar to the $2725 \pm 2 \mathrm{Ma}$ age of amphibole-biotite gneisses. Base on the previous dada provided, the oldest $\mathrm{U}-\mathrm{Pb}$ age in $3149 \pm 46 \mathrm{Ma}[10]$ and $\mathrm{Sm}-\mathrm{Nd}$ model ages showed the age of protolite age at 3.1-2.8 Ga It may reflect the second stage of the tonalite emplacement, or the metamorphism stage associated with the mafic dikes' intrusion. The lower intercept of $807 \mathrm{Ma}$ has no geological sense or reflects the cumulative effect of modern lead loss and some ancient geological events. The lower intercepts in this case do not correspond to any known event within the NW Baltic Shield. 
Table 2. Isotope $\mathrm{U}-\mathrm{Pb}$ single zircon data with 205Pb-tracer for zircon from the Ingozero massif gneisses [31].

\begin{tabular}{|c|c|c|c|c|c|c|c|c|c|c|}
\hline \multirow{2}{*}{ No. } & \multirow{2}{*}{ Sample (mg) } & \multicolumn{2}{|c|}{ Concentration (ppm) } & \multicolumn{4}{|c|}{ Isotope Ratios } & \multicolumn{3}{|c|}{ Age (Ma) } \\
\hline & & $\mathrm{Pb}$ & $\mathrm{U}$ & ${ }^{206} \mathrm{~Pb} /{ }^{204} \mathrm{~Pb}$ & ${ }^{206} \mathrm{~Pb} /{ }^{238} \mathrm{U} \pm 2 \sigma$ & ${ }^{207} \mathrm{~Pb}^{/ 235} \mathrm{U} \pm 2 \sigma$ & ${ }^{207} \mathrm{~Pb} / 206 \mathrm{~Pb} \pm 2 \sigma$ & ${ }^{206} \mathrm{~Pb} /{ }^{238} \mathrm{U} \pm 2 \sigma$ & ${ }^{207} \mathrm{~Pb} /{ }^{235} \mathrm{U} \pm 2 \sigma$ & ${ }^{207} \mathrm{~Pb} /{ }^{206} \mathrm{~Pb} \pm 2 \sigma$ \\
\hline & & & & & & $\mathrm{H}-10-07$ & & & & \\
\hline 2 & 0.063 & 72.24 & 132.67 & 2202.2 & $0.491 \pm 0.001$ & $12.576 \pm 0.030$ & $0.1859 \pm 0.0001$ & $2574 \pm 6$ & $2648 \pm 6$ & $2706 \pm 2$ \\
\hline 3 & 0.090 & 50.86 & 99.21 & 2848.4 & $0.488 \pm 0.002$ & $12.498 \pm 0.041$ & $0.1848 \pm 0.0002$ & $2563 \pm 8$ & $2638 \pm 9$ & $2696 \pm 2$ \\
\hline \multirow[t]{2}{*}{4} & 0.084 & 61.15 & 145.36 & 579.9 & $0.378 \pm 0.002$ & $9.180 \pm 0.074$ & $0.1762 \pm 0.0009$ & $2066 \pm 11$ & $2356 \pm 19$ & $2617 \pm 14$ \\
\hline & & & & & & H-10-08 & & & & \\
\hline 3 & 0.0788 & 214.7 & 78.95 & 354.1 & $0.470 \pm 0.002$ & $11.867 \pm 0.071$ & $0.1831 \pm 0.0007$ & $2484 \pm 11$ & $2594 \pm 15$ & $2681 \pm 10$ \\
\hline 4 & 0.0300 & 160.2 & 331.14 & 1345.1 & $0.452 \pm 0.002$ & $11.286 \pm 0.065$ & $0.1812 \pm 0.0005$ & $2403 \pm 12$ & $2547 \pm 15$ & $2664 \pm 7$ \\
\hline 5 & 0.0157 & 285.3 & 629.85 & 1129.9 & $0.424 \pm 0.001$ & $10.412 \pm 0.053$ & $0.1763 \pm 0.0006$ & $2279 \pm 8$ & $2463 \pm 13$ & $2619 \pm 9$ \\
\hline 6 & 0.0137 & 193.8 & 449.45 & 1012.9 & $0.363 \pm 0.002$ & $8.506 \pm 0.062$ & $0.1699 \pm 0.0006$ & $1997 \pm 12$ & $2287 \pm 17$ & $2556 \pm 8$ \\
\hline
\end{tabular}


Table 3. Isotope $\mathrm{U}-\mathrm{Pb}$ data for zircons from the Ingozero massif gneisses.

\begin{tabular}{|c|c|c|c|c|c|c|c|c|c|}
\hline \multirow{2}{*}{ No. } & \multirow{2}{*}{ Sample (mg) } & \multicolumn{2}{|c|}{ Concentrations (ppm) } & \multicolumn{3}{|c|}{ Isotope Ratios } & \multicolumn{3}{|c|}{ Isotope Ratios and Age (Ma) } \\
\hline & & $\mathrm{Pb}$ & $\mathbf{U}$ & ${ }^{206} \mathrm{~Pb} /{ }^{204} \mathrm{~Pb}$ & ${ }^{206} \mathrm{~Pb} /{ }^{207} \mathrm{~Pb}$ & ${ }^{206} \mathrm{~Pb} /{ }^{208} \mathrm{~Pb}$ & ${ }^{207} \mathrm{~Pb} /{ }^{235} \mathrm{U}$ & ${ }^{206} \mathrm{~Pb} /{ }^{238} \mathrm{U}$ & ${ }^{207} \mathrm{~Pb} /{ }^{206} \mathrm{~Pb}$ \\
\hline & & & & & H-10-09 & & & & \\
\hline 1 & 2.9 & 23.3 & 628.1 & 1062 & 8.5147 & 0.17243 & 4.06158 & 0.29323 & 1715 \\
\hline & & & & & H-10-05 & & & & \\
\hline 1 & 0.3 & 82.4 & 239.9 & 1024 & 6.5529 & 13.3470 & 6.1811 & 0.32044 & 2230 \\
\hline 2 & 0.2 & 98.1 & 322.9 & 1041 & 6.4917 & 13.2260 & 5.5247 & 0.28303 & 2250 \\
\hline 3 & 0.4 & 124.0 & 458.2 & 2020 & 6.7525 & 15.0670 & 5.0309 & 0.25732 & 2250 \\
\hline & & & & & H-10-10 & & & & \\
\hline 1 & 0.7 & 40.1 & 137.2 & 1731 & 5.6024 & 14.9253 & 6.42885 & 0.27171 & 2573 \\
\hline 2 & 0.6 & 29.8 & 110.3 & 1040 & 5.4114 & 12.3978 & 5.88431 & 0.24636 & 2589 \\
\hline 3 & 0.5 & 50.2 & 222.6 & 4910 & 6.0210 & 21.9358 & 5.09592 & 0.21282 & 2593 \\
\hline & & & & & H-10-06 & & & & \\
\hline 1 & 0.3 & 151.4 & 349.9 & 2084 & 5.6203 & 24.6585 & 9.75653 & 0.41097 & 2579 \\
\hline 2 & 0.8 & 120.0 & 348.2 & 2848 & 5.8437 & 16.6376 & 7.46117 & 0.32416 & 2527 \\
\hline 3 & 0.7 & 104.5 & 340.8 & 4911 & 6.0210 & 21.9358 & 6.62618 & 0.29355 & 2494 \\
\hline & & & & & H-10-07 & & & & \\
\hline 1 & 0.3 & 237.0 & 446.0 & 6492 & 5.4606 & 61.8460 & 12.8503 & 0.51422 & 2665 \\
\hline 5 & 0.3 & 135.2 & 470.6 & 1459 & 5.9225 & 22.6140 & 6.0202 & 0.27257 & 2458 \\
\hline & & & & & H-10-08 & & & & \\
\hline 1 & 0.3 & 73.3 & 129.2 & 725 & 4.9011 & 14.2990 & 13.1091 & 0.50759 & 2720 \\
\hline 2 & 0.2 & 66.2 & 120.4 & 622 & 4.8854 & 12.3480 & 12.3851 & 0.48518 & 2700 \\
\hline & & & & & H-10-01 & & & & \\
\hline 1 & 0.5 & 112.3 & 228.8 & 2427 & 5.2943 & 29.2260 & 11.7632 & 0.46401 & 2690 \\
\hline 2 & 0.7 & 385.5 & 827.7 & 7759 & 5.3717 & 24.6380 & 11.2165 & 0.44070 & 2695 \\
\hline 3 & 0.7 & 308.9 & 707.0 & 4507 & 5.3774 & 19.3060 & 10.3353 & 0.40904 & 2680 \\
\hline 4 & 0.4 & 215.1 & 550.5 & 2640 & 5.3395 & 18.9080 & 9.1753 & 0.36432 & 2680 \\
\hline
\end{tabular}


The zircon grains from the biotite-amphibole gneiss (H-10-06) are represented by dark-brown to brown prismatic and isometric crystals. The following zircon fractions were taken for the $\mathrm{U}-\mathrm{Pb}$ dating: The first is dark-brown prismatic and isometric crystals with a highly corroded surface; the second is brown fissured, slightly transparent zircon of prismatic to long-prismatic type, the grains were fragmented, the most suitable parts were selected; the third one is brown fissured, slightly transparent zircon of prismatic to long-prismatic type. Three data points yielded the age of $2615 \pm 8 \mathrm{Ma}$ (Table 3 and Figure 9d). The obtained age is interpreted as the region granitization time. The lower intercept of 389 Ma could reflect the influence of Paleozoic 408-360 Ma alkaline magmatism widely developed within the Kola region.

The zircon grains of pegmatite vein (N-10-10) are represented by dark-brown to light-brown crystals from short- to long-prismatic type. Zircon grains were picked for the U-Pb dating from three size fractions: from -0.15 to $+0.1 \mathrm{~mm}$-slightly fissured dark-brown zircon of short-prismatic to prismatic type (No. 1); from $+0.15 \mathrm{~mm}$-slightly fissured dark-brown transparent zircon of short-prismatic to prismatic type (No. 2); from -0.15 to $+0.1 \mathrm{~mm}$-nonfractured light brown transparent zircon of prismatic to long-prismatic type (No. 3). The discordia for the three data points has the upper intercept with the concordia at $2549 \pm 31 \mathrm{Ma}$ (Table 3; Figure 9e, points 1-3), corresponding to the pegmatite veins formation among the gneisses.

The zircon grains from the plagiogranite (H-10-05) are represented by brown to pale-brown prismatic to long-prismatic transparent zircon grains. The three zircon fractions were picked for the $\mathrm{U}-\mathrm{Pb}$ dating: the pale-brown short- to long-prismatic grains with the length-to-width ratio 1.5-2 (No. 1); the brown short- to long-prismatic grains with the length-to-width ratio 1.7-2.5 (No. 2); the pale-brown short- to long-prismatic grains (No. 3). The three data points yielded the age of $2208 \pm 17 \mathrm{Ma}$ (Table 3 and Figure 9f). The obtained age is interpreted as the plagiogranite crystallization time.

Fragments of a fractured and opaque yellow-brown monazite were selected for the U-Pb isotopic dating from the granite vein (N-10-09). The data point of the selected monazite provides a concordant age of $1664 \pm 7 \mathrm{Ma}$ (Table 3 and Figure 9e, point 4), interpreted as the granite vein crystallization time.

The isotope Sm-Nd model ages (TDM) determined for the TTG gneisses of the Ingozero massif (Table 4) are equal to the biotite gneisses (H-10-01), and are $2820 \mathrm{Ma}$; $3019 \mathrm{Ma}$ for the amphibole-biotite gneisses (H-10-07); $2936 \mathrm{Ma}$ for the biotite-amphibole gneisses (H-10-08). The model ages obtained earlier for the gneisses of the Ingozero complex [7] are in the range of 3.1-2.9 Ga, which is similar to the period of the formation of the initial melts from the gneisses protolite melts that occurred in the range of 3.1-2.8 Ga. The Sm-Nd ages for the gneisses are older than the $\mathrm{U}-\mathrm{Pb}$ zircon data, so we propose the zircon ages as the metamorphic ages.

Table 4. Isotope Sm-Nd data for gneisses of the Ingozero TTG massif; samples markeb by $\left(^{*}\right)$ are sited in [7].

\begin{tabular}{ccccccc}
\hline \multirow{2}{*}{ Sample } & \multicolumn{2}{c}{ Sample $\mathbf{( m g )}$} & \multicolumn{2}{c}{ Isotope Ratios } & Err & Age (Ma) \\
\cline { 2 - 7 } & $\mathbf{S m}$ & $\mathbf{N d}$ & ${ }^{\mathbf{1 4 7}} \mathbf{S m} /{ }^{\mathbf{1 4 4}} \mathbf{N d}$ & ${ }^{\mathbf{1 4 3}} \mathbf{N d} /{ }^{\mathbf{1 4 4}} \mathbf{N d}$ & & $\mathbf{T}(\mathbf{D M})$ \\
\hline $\mathrm{H}-10-01$ & 2.14 & 13.79 & 0.09370 & 0.51091 & 12 & 2828 \\
$\mathrm{H}-10-07$ & 2.93 & 13.28 & 0.13320 & 0.51155 & 22 & 3019 \\
$\mathrm{H}-10-08$ & 3.77 & 22.32 & 0.10203 & 0.51099 & 11 & 2936 \\
$21 \mathrm{~K} 02\left(^{*}\right)$ & 1.49 & 8.47 & 0.10651 & 0.51097 & 14 & 2950 \\
T20 K02 $\left(^{*}\right)$ & 1.51 & 8.50 & 0.10732 & 0.51090 & 11 & 3081 \\
$1 \mathrm{~K} 02 \mathrm{~A}\left(^{*}\right)$ & 2.18 & 11.36 & 0.11589 & 0.51119 & 5 & 2893 \\
$2 \mathrm{~K} 02\left(^{*}\right)$ & 2.54 & 15.50 & 0.09893 & 0.51088 & 17 & 2881 \\
\hline
\end{tabular}

The age of $3149 \pm 46$ Ma obtained for individual zircon grains from biotite gneisses of the Ingozero massif may be the earliest stage of magmatic crystallization of the tonalites [10]. The ages of $2697 \pm 9 \mathrm{Ma}$ for biotite gneisses, $2725 \pm 2 \mathrm{Ma}$ and $2667 \pm 7 \mathrm{Ma}$ for amphibole-biotite gneisses, and $2727 \pm 5 \mathrm{Ma}$ and $2615 \pm 8 \mathrm{Ma}$ for biotite-amphibole gneisses are younger and most likely correspond to the time 
of the metamorphism and deformation of the rocks. The crystallization ages are $2208 \pm 7 \mathrm{Ma}$ for the plagiogranites, $2549 \pm 31 \mathrm{Ma}$ for the pegmatite veins among the gneisses, and $1664 \pm 7 \mathrm{Ma}$ for the granite veins.

\subsubsection{Pechenga Frame}

Two generations of zircon grains were noted in the garnet-biotite gneisses sample (VII): Prismatic crystals with a complex internal structure and the metamorphic homogeneous prismatic crystals and shells over the earlier crystal grains. Three points of the metamorphic zircon yielded an age of $2810 \pm 150 \mathrm{Ma}$. This age is preliminary and evaluated for 3 points only, and interpreted as the time of metamorphism of the garnet-biotite gneisses.

Three generations of zircon were distinguished in the metagabbro sample (II): Magmatic pink prismatic crystals with uneven faces; metamorphic brown crystals of short-prismatic habit with developed irrational faces; and metamorphic pink homogeneous zircon. The discordia for three data points of the magmatic zircon (Table 5 and Figure 10a) has the upper intercept with the concordia at $2587 \pm 5 \mathrm{Ma}$, corresponding to the gabbros emplacement time. The U-Pb upper intercept age for the metamorphic zircon (three data points) (Table 5 and Figure 10a) is equal to $2507 \pm 7$ Ma and corresponds to the time of metamorphism of the gabbros.
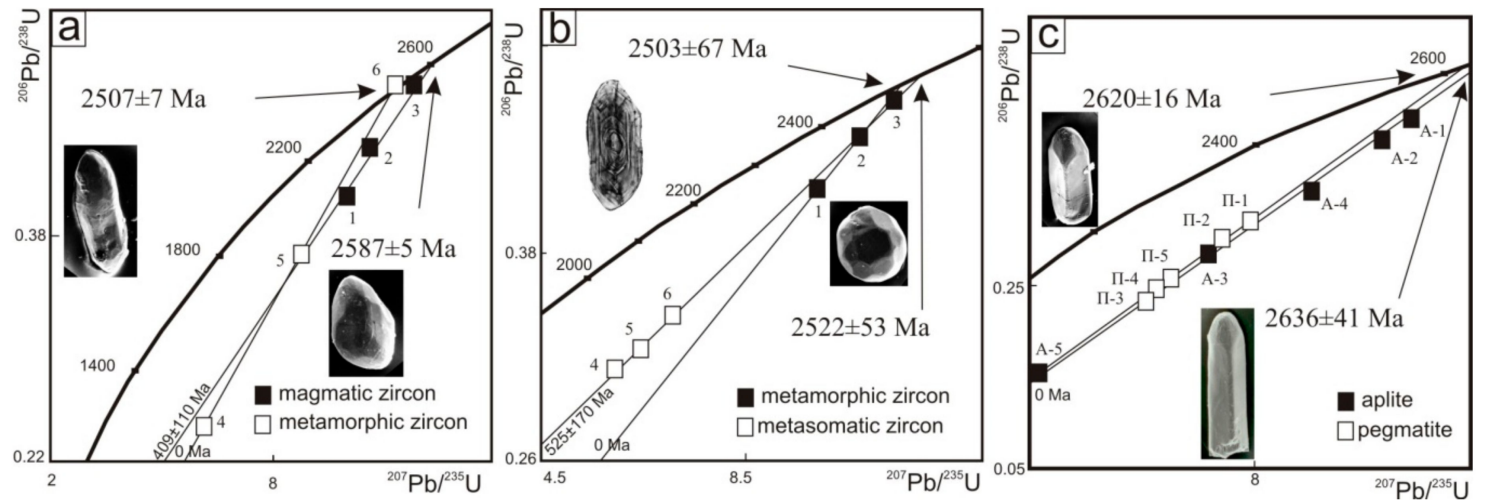

Figure 10. U-Pb isotope diagram with concordia: (a) for zircon from metagabbro (II); (b) for zircon from iron quartzites (III); and (c) for zircon from aplites (A1-A7) and pegmatites (П1-П5).

There are three generations of zircon in the iron quartzite sample (III): The xenogenic amphibolite zircon, the metamorphic prismatic (pink homogeneous crystals), and the metamorphic pink isometric (formed with an excess of silica and iron additives). The three data points of metamorphic zircon and the three data points of metasomatic zircon (Table 5 and Figure 10b) yielded ages, which corresponded to $2503 \pm 67 \mathrm{Ma}$ and $2522 \pm 53 \mathrm{Ma}$. They were interpreted as the time of the origin of the quartz metasomatites.

The zircon $\mathrm{Zr} / \mathrm{Hf}$ ratios in the biotite gneisses vary from 41.41 to 49.46 , from 44.4 to 45.1 in amphibolites, and from 48.42 to 60.27 in quartz metasomatites; these ratios correspond to the average $\mathrm{Zr} / \mathrm{Hf}$ ratios of zircon in all rocks of these types.

In the aplite sample (A) two generations of zircon were recognized: Pink-, long-, and short-prismatic hyacinth type crystals are the bulk of the sample (85\%). Brown long-prismatic crystals are present in a smaller amount of up to $15 \%$. Five fractions of pink zircon yielded the age of $2636 \pm 41 \mathrm{Ma}$ (Table 5 and Figure 10c), corresponding to the age of the aplite crystallization.

There are short-prismatic zircon crystals in the pegmatite $(\mathrm{P})$ with zircon color, which varies from colorless to yellow and brown. The five data points yielded the age (Table 5 and Figure 10c) of $2620 \pm 16 \mathrm{Ma}$, corresponding to the time of the pegmatite crystallization. 
Table 5. U-Pb isotope data for zircon from rocks of the Polygon, Pereval, and Malonemetskaya Bay outcrops.

\begin{tabular}{|c|c|c|c|c|c|c|c|c|c|}
\hline \multirow{2}{*}{ No. } & \multirow{2}{*}{ Sample (mg) } & \multicolumn{2}{|c|}{ Concentration (ppm) } & \multicolumn{3}{|c|}{ Isotope Ratios } & \multicolumn{3}{|c|}{ Isotope Ratios and Age (Ma) } \\
\hline & & $\mathrm{Pb}$ & $\mathrm{U}$ & ${ }^{206} \mathrm{~Pb} /{ }^{204} \mathrm{~Pb}$ & ${ }^{206} \mathrm{~Pb} /{ }^{207} \mathrm{~Pb}$ & ${ }^{206} \mathrm{~Pb} /{ }^{208} \mathrm{~Pb}$ & ${ }^{207} \mathrm{~Pb} /{ }^{235} \mathrm{U}$ & ${ }^{206} \mathrm{~Pb} /{ }^{238} \mathrm{U}$ & ${ }^{207} \mathrm{~Pb} /{ }^{206} \mathrm{~Pb}$ \\
\hline \multicolumn{10}{|c|}{ A-1 } \\
\hline A-1 & 0.6 & 32 & 59 & 1230 & 5.359 & 4.833 & 10.669 & 0.4377 & 2623 \\
\hline A-2 & 0.7 & 31 & 73 & 1219 & 5.158 & 4.532 & 10.238 & 0.4199 & 2623 \\
\hline A-3 & 0.5 & 43 & 104 & 945 & 4.792 & 3.698 & 7.181 & 0.2899 & 2650 \\
\hline A-4 & 1.2 & 23 & 48 & 1210 & 5.203 & 4.392 & 8.891 & 0.3583 & 2653 \\
\hline A-5 & 0.5 & 55 & 208 & 1139 & 5.056 & 4.012 & 3.719 & 0.1568 & 2578 \\
\hline A- 6 & 0.4 & 161 & 281 & 834 & 4.774 & 3.647 & 9.197 & 0.3854 & 2588 \\
\hline A-7 & 0.4 & 77 & 194 & 1086 & 5.249 & 3.853 & 6.821 & 0.2922 & 2550 \\
\hline \multicolumn{10}{|c|}{ П-1 } \\
\hline П-1 & 0.65 & 192 & 523 & 605 & 5.125 & 12.184 & 7.899 & 0.3274 & 2606 \\
\hline$\Pi-2$ & 0.6 & 224 & 647 & 505 & 5.080 & 10.887 & 7.317 & 0.3033 & 2606 \\
\hline П-3 & 0.65 & 193 & 739 & 658 & 5.723 & 14.540 & 5.753 & 0.2399 & 2596 \\
\hline$\Pi-4$ & 1.0 & 535 & 1027 & 723 & 5.983 & 11.893 & 5.984 & 0.2489 & 2600 \\
\hline П-5 & 1.0 & 521 & 965 & 810 & 6.039 & 15.332 & 6.304 & 0.2633 & 2593 \\
\hline \multicolumn{10}{|c|}{ III } \\
\hline 1 & 0.9 & 134 & 307 & 1400 & 5.710 & 19.7800 & 9.5058 & 0.4142 & 2522 \\
\hline 2 & 0.4 & 271 & 460 & 210 & 4.436 & 4.8860 & 10.2244 & 0.4470 & 2517 \\
\hline 3 & 1.1 & 231 & 471 & 2450 & 5.910 & 22.7400 & 10.6181 & 0.4683 & 2502 \\
\hline 4 & 0.9 & 110 & 330 & 1050 & 6.048 & 15.6602 & 6.6430 & 0.3133 & 2388 \\
\hline 5 & 0.9 & 78 & 215 & 510 & 5.560 & 9.5970 & 6.8971 & 0.3218 & 2407 \\
\hline 6 & 0.3 & 155 & 368 & 260 & 4.900 & 6.1076 & 7.4310 & 0.3433 & 2424 \\
\hline \multicolumn{10}{|c|}{ II } \\
\hline 1 & 1.4 & 35 & 80 & 1200 & 5.570 & 12.7700 & 9.5616 & 0.4097 & 2551 \\
\hline 2 & 1.5 & 46 & 89 & 450 & 5.116 & 7.6562 & 10.3361 & 0.4449 & 2543 \\
\hline 3 & 2.5 & 46 & 70 & 210 & 4.330 & 4.3500 & 11.5915 & 0.4868 & 2584 \\
\hline 4 & 0.7 & 126 & 458 & 580 & 5.312 & 8.6140 & 5.5593 & 0.2408 & 2533 \\
\hline 5 & 0.6 & 81 & 197 & 580 & 5.320 & 8.6800 & 8.3906 & 0.3643 & 2528 \\
\hline 6 & 1.0 & 89 & 151 & 300 & 4.878 & 6.3490 & 11.0325 & 0.4856 & 2505 \\
\hline
\end{tabular}




\section{Discussion}

The petrochemical and geochemical characteristics of the Ingozero rocks are similar to those of tonalite-trondhjemite-granodiorite (TTG) complexes established on other Archaean Shields. The isotope $\mathrm{U}-\mathrm{Pb}$ dating of individual zircon grains from the biotite gneisses yielded the oldest age of $3149 \pm 46 \mathrm{Ma}$ for the Ingozero gneisses magmatic protolith [10]. Model Sm-Nd ages have shown the formation of the gneisses protolith initial melt occurred at 3.1-2.8 Ga. The ages of metamorphic processes were determined by isotope U-Pb dating (ID TIMS): biotite gneisses-2697 $\pm 9 \mathrm{Ma}$; amphibole-biotite gneisses $-2725 \pm 2 \mathrm{Ma}$ and $2667 \pm 7 \mathrm{Ma}$; and biotite-amphibole gneisses $2727 \pm 5 \mathrm{Ma}$ and $2615 \pm 8 \mathrm{Ma}$. The ages for granitoids cut the deformed gneisses are $2208 \pm 7 \mathrm{Ma}$ and $2549 \pm 31 \mathrm{Ma}$ for plagiogranites and pegmatoid veins in gneisses, respectively.

The Pechenga frame outcrops contain the most ancient rocks of the area, i.e., the garnet-biotite and biotite gneisses with the metamorphism age of $2.8 \mathrm{Ga}$ and granodiorites with the crystallization age of $2722 \pm 9 \mathrm{Ma}$ [19]; the pegmatites and aplites formed within the gneisses during the second deformation stage and have the ages of $2620 \pm 16 \mathrm{Ma}$ and $2636 \pm 41 \mathrm{Ma}$, correspondingly, marking the final stage of Archaean evolution in the area. The metagabbro has a crystallization age of $2587 \pm 5 \mathrm{Ma}$ and is currently represented by metamorphosed and boudinaged bodies of amphibolites with the metamorphism age of $2507 \pm 7 \mathrm{Ma}$; the iron quartzite formed during the stage of gabbros metamorphism and deformations have ages of $2522 \pm 53 \mathrm{Ma}$ and $2503 \pm 67 \mathrm{Ma}$.

Author Contributions: Conceptualization, N.K. (Nikolay Kozlova) and T.K.; methodology, N.K. (Nikolay Kozlova); software, E.N.; validation, E.N., T.K., and N.K. (Nikolay Kozlov); formal analysis, E.N.; investigation, E.N. and T.K.; resources, N.K. (Nikolay Kozlov); data curation, N.K. (Nikolay Kozlov) and T.K.; writing —original draft preparation, E.N.; writing-review and editing, T.K. and N.K. (Nikolay Kozlov); visualization, E.N. and N.K. (Natalia Kozlova); supervision, N.K. (Nikolay Kozlov); project administration, T.K. and N.K. (Nikolay Kozlov); funding acquisition, N.K. (Nikolay Kozlov).

Funding: This research was funded by GI KSC RAS program 0226-2019-0052 and Fundamental Program of the Presidium of RAS section "Fundamental geological and geophysical research of the lithosphere processes".

Acknowledgments: Authors are grateful for consultations (GI KSC RAS) on zircon mineralogy to A.V. Voloshin; for zircon photos to Savchenko E.E. and Denisenko O.V.; for sample procedures: (a) crushing-to Koval L.I., (b) zircon dissolution - to Apanasevich E.A. and Levkovich N.V.; REE analysis (IGM SO RAN)—Turkina O.M. and Travin A.V.

Conflicts of Interest: The authors declare no conflict of interest.

\section{References}

1. Mitrofanov, F.P. Actual questions and some answers of the Precambrian geology of cratons. Litosfera 2001, 21, 5-14. (In Russian)

2. Radchenko, A.T.; Balagansky, V.V.; Vinogradov, A.N.; Golionko, A.T.; Petrov, V.P.; Pozilenko, V.I.; Radchenko, M.K. Precambrian Tectonic of the North-Eastern Part of the Baltic Shield (Explanatory Note for the Tectonic Map of the N-E Baltic Shield 1: 500,000)/Resp; Mitrofanov, F.P., Ed.; KBAS USSR: Apatity, Russia, 1992; p. 112. (In Russian)

3. Radchenko, A.T.; Balagansky, V.V.; Basalayev, A.A.; Belyaev, O.A.; Pozilenko, V.I.; Radchenko, M.K. Explanatory Note for the Geological Map of the North-Eastern Part of the Baltic Shield, Scale 1: 500,000; Mitrofanov, F.P., Ed.; KSC RAS: Apatity, Russia, 1994; p. 95. (In Russian)

4. Balagansky, V.V. Main Stages of the Tectonic Development of the Paleoproterozoic NE Baltic Shield. Ph.D. Thesis, Institute of Precambrian Geology and Geochronology RAS, Saint-Petersburg, Russia, 2002. (In Russian).

5. Goldberg, I.J.; Pushkin, G.J.; Nikitichev, A.P.; Smolkov, A.S.; Zagorodnij, V.G.; Predovskiy, A.A. Report on Geological Exploration of the Imandra-Varzuga Zone on a Scale 1:200,000 and Geochemical Searches on a Scale 1:100,000 of 1974-1978 in Kirovsk-Apatity, Lovozero and Terskiy Regions; GI KFAN: Apatity, Russia, 1978; p. 371. (In Russian)

6. Batieva, I.D.; Belkov, I.V. Granitoid units of the Kola Peninsula. In Profiles on Petrology and Metallogeny of the Kola Peninsula; Nauka: Saint Petersburg, Russia, 1968; pp. 5-143. (In Russian) 
7. Kozlov, N.E.; Sorohtin, N.O.; Glaznev, V.N.; Kozlova, N.E.; Ivanov, A.A.; Kudrjashov, N.M.; Martinov, E.V.; Tjuremnov, V.A.; Matjushkin, A.V.; Osipenko, L.G. Geology of the Archaean Baltic Shield; Nauka: Saint Petersburg, Russia, 2006; p. 329. (In Russian)

8. Zagorodniy, V.G.; Radchenko, A.T. Principles and main features of the tectonic zoning in the north-eastern part of the Baltic Shield. In Tectonic and Deep Structure of the North-Eastern Part of the Baltic Shield; KBAS USSR: Apatity, Russia, 1978; pp. 3-12. (In Russian)

9. Belkov, I.V.; Zagorodniy, V.G.; Predovskiy, A.A. Stratigraphic Dismemberment and Correlation of the North-Eastern Part of the Precambrian Baltic Shield; Nauka: Leningrad, Russia, 1971; pp. 141-150. (In Russian)

10. Bayanova, T.B.; Kunakkuzin, E.L.; Serov, P.A.; Fedotov, D.A.; Borisenko, E.S.; Elizarov, D.V.; Larionov, A.V. Precise U-Pb (ID-TIMS) and SHRIMP-II ages on single zircon and Nd-Sr signatures from Achaean TTG and high aluminum gneisses on the Fennoscandian Shield. In Proceedings of the 32nd Nordic Geological Winter Meeting, Helsinki, Finland, 13-15 January 2016; p. 172.

11. Vrevskiy, A.B.; Bogomolov, E.S.; Zinger, T.F.; Sergeev, S.A. Source polychronism and isotope age of a volcanogenic complex (Arvarenchskaya suite) within the Imandra-Varzugskaia structure, the Kola Peninsula. Dokl. Earth Sci. 2010, 431, 377-381.

12. Kojevnikov, V.N.; Skublov, S.G.; Marin, J.B.; Medvedev, P.V.; Sjstra, J.; Valensia, V. Hadei-Archaean detrital zircons from Yatulian quarzites and conglomerates of the Karelian Craton. Dokl. Earth Sci. 2010, 431, 85-90.

13. Vetrin, V.R.; Belousova, E.A.; Kremenetskyc, A.A. Lu-Hf Isotopic Systematics of Zircon from Lower Crustal Xenoliths in the Belomorian Mobile Belt. Geol. Ore Depos. 2018, 60, 568-577. [CrossRef]

14. Savitsky, A.V.; Gromov, J.A.; Mel'nikov, E.V.; Sharikov, P.I. Uranium mineralization of the Litsa Region on the Kola Peninsula (Russia). Geol. Ore Depos. 1995, 5, 403-416. (In Russian)

15. Vinogradov, A.N.; Vinogradova, G.V. Metamorphism of the Kola series rocks and the problem of assessing the prospects of the micaceousness of the northwestern part of the Murmansk Region. In Problems of Studying and Developing the Natural Resources of the North; KBAS USSR: Apatity, Russia, 1973; pp. 19-30. (In Russian)

16. Belyaev, O.A. Progressive zonal metamorphism of the north-western part of the early Proterozoic Kola Peninsula. In Metamorphism of Precambrian Complexes (Kola Peninsula); KBAS USSR: Apatity, Russia, 1976; pp. 31-49. (In Russian)

17. Mitrofanov, F.; Bayanova, T.B.; Balabonin, N.L.; Sorohtin, N.O.; Pozhilenko, V.I. The Kolskaya hypogene early Cambrian collision: New geological, geochronological, geodynamical and metallogenical data. Vestn. St.-Petersburg Univ. 1997, 7, 5-8. (In Russian)

18. Vetrin, V.R.; Rodionov, N.V.; Serov, P.A. Age, Sm-Nd Systematics, and Geochemistry of Tonalite-Trondhjemite-Granodiorite Gneisses of the Northern Part of the Baltic Shield. Earth Sci. Rep. 2013, 452, 930-935. [CrossRef]

19. Kozlov, N.E.; Martynov, E.V.; Kozlova, N.E.; Kaulina, T.V.; Smirnov, Y.P. Petrochemical systematics of amphibolites of the Archaean part of the Kola superdeep well section. Geochemistry 2007, 45, 123-130. [CrossRef]

20. Kharitonov, L.Y. The Structure and Stratigraphy of the Karelides from the Eastern Part of the Baltic Shield; Nedra: Moscow, Russia, 1966; p. 360. (In Russian)

21. Polkanov, A.A. Geological and Petrological Sketch of the North-Western Part of the Kola Peninsula, Part 1; Nedra: Moscow, Russia, 1935; p. 565. (In Russian)

22. Goryainov, P.M. Kola-Norwegian megablock-The oldest craton of the Precambrian Kola Peninsula. In Regional Tectonics of the Early Precambrian of the USSR; Nauka: Leningrad, Russia, 1980; pp. 88-103. (In Russian)

23. Goryainov, P.M.; Balabonin, N.L. Structural-Material Parageneses of Iron Ores of the Precambrian Kola Peninsula; Nauka: Saint Petersburg, Russia, 1988; p. 144. (In Russian)

24. Kaulina, T.V. Formation and Transformation of Zircon in Polymetamorphic Complexes; Publishing House KSC RAS: Apatity, Russia, 2010; p. 144. (In Russian)

25. Krogh, T.E. A low-contamination method for hydrothermal decomposition of zircon and extraction of $U$ and $\mathrm{Pb}$ for isotopic age determination. Geochim. Cosmochim. Acta 1973, 37, 485-494. [CrossRef]

26. Steiger, R.H.; Jager, E. Subcommission on geochronology: Convention on the use of constants in geo- and cosmochronology. Earth Planet. Sci. Lett. 1977, 36, 359-362. [CrossRef]

27. Ludwig, K.R. PBDAT, A Computer Program for Processing Pb-U-Th Data, v. 1.20; United Geological Survey Open-File Report; U.S. Geological Survey: Reston, VA, USA, 1991; 38p. 
28. Ludwig, K.R. User's Manual for Isoplot, v. 3.0, A Geochronological Toolkit for Microsoft Excel; Berkeley Geochronolgy Center: Berkeley, CA, USA, 2008.

29. Stacey, J.S.; Kramers, J.O. Approximation of terrestrial lead isotope evolution by a two-stage model. Earth Planet. Sci. Lett. 1975, 26, 207-221. [CrossRef]

30. Mitrofanov, F.P.; Pozhilenko, V.I.; Smolkin, V.F.; Arzamastsev, A.A.; Ya, V.; Yevzerov, V.V.; Lyubtsov, E.V.; Shipilov, S.B.; Nikolaeva, Z.; Fedotov, A. Geology of the Kola Peninsula; Mitrofanov, F.P., Ed.; GI KSC RAS: Apatity, Russia, 1995; p. 145.

31. Nitkina, E.A.; Bayanova, T.B. Isotope-geochronology study of the Ingozero massif (Kola Peninsula). Vestnik MSTU 2018, 21, 51-60. (In Russian)

32. Predovskiy, A.A. Reconstruction of the Conditions of the Early Precambrian Sedimentogenesis and Volcanism; Nauka: Saint Petersburg, Russia, 1980; p. 152. (In Russian)

33. O'Connor, J.T. A classification for quartz-rich igneous rocks based on feldspar ratios. Geol. Surv. Prof. Pap. $1965,527,79$.

34. Boynton, W.V. Cosmochemistry of the rare earth elements: Meteorite studies, Chapter 3. In Rare Earth Element Geochemistry. Developments in Geochemistry; Henderson, P., Ed.; Elsevier: Amsterdam, The Netherlands, 1985; Volume 2, pp. 1515-1522.

35. Moyen, J.-F.; Martin, H. Forty years of TTG research. Lithos 2012, 148, 312-336. [CrossRef]

36. Watson, E.B.; Harrison, T.M. Zircon saturation revisited: Temperature and composition effects in a variety of crustal magma types. Earth Planet. Sci. Lett. 1983, 64, 295-304. [CrossRef]

37. Turkina, O.M.; Kapitonov, I.N. Isotope Lu-Hf zircon composition as indicator of the melt sources for Paleoproterozoic orogenic granites. Geol. Geophys. 2017, 58, 181-199.

(C) 2019 by the authors. Licensee MDPI, Basel, Switzerland. This article is an open access article distributed under the terms and conditions of the Creative Commons Attribution (CC BY) license (http://creativecommons.org/licenses/by/4.0/). 